\title{
Complete genome sequencing and comparative genomic analyses of Bacillus sp. S3, a novel hyper Sb(III)-oxidizing bacterium
}

Jiaokun Li

Central South University

Tianyuan Gu

Central South University

Weimin Zeng ( $\square$ zengweimin1024@126.com )

Central South University https://orcid.org/0000-0002-7155-6386

Runlan Yu

Central South University

Yuandong Liu

Central South University

Xueling Wu

Central South University

Li Shen

Central South University

Guanzhou Qiu

Central South University

Liang Zhi Li

Central South University

\section{Research article}

Keywords: Bacillus sp. S3, Sb(III)-resistance, genome sequencing, comparative genome, heavy metal (loid)

Posted Date: January 27th, 2020

DOI: https://doi.org/10.21203/rs.2.17919/v2

License: (c) This work is licensed under a Creative Commons Attribution 4.0 International License. Read Full License

Version of Record: A version of this preprint was published at BMC Microbiology on May 1st, 2020. See the published version at https://doi.org/10.1186/s12866-020-01737-3. 


\section{Abstract}

Background: Antimonite [Sb(III)]-oxidizing bacterium has great potential in the environmental bioremediation of Sbpolluted sites. Bacillus sp. S3 that was previously isolated from antimony-contaminated soil displayed high Sb(III) resistance and $\mathrm{Sb}$ (III) oxidation efficiency. However, the genomic information and evolutionary feature of Bacillus sp. S3 are very scarce.

Results: Here, we identified a 5,579,638 bp chromosome with $40.30 \%$ GC content and a 241,339 bp plasmid with $36.74 \%$ GC content in the complete genome of Bacillus sp. S3. Genomic annotation showed that Bacillus sp. S3 contained a key aioB gene potentially encoding $\mathrm{As}$ (III)/Sb(III) oxidase, which was not shared with other Bacillus strains. Further, a series of genes associated with $\mathrm{Sb}$ (III) and other heavy metal(loid)s were also ascertained in Bacillus sp. S3, reflecting its adaptive advantage for growth in the harsh eco-environment. Based on the analysis of phylogenetic relationship and the average nucleotide identities (ANI), we found that Bacillus sp. S3 was a novel species within the Bacillus genus. The majority of mobile genetic elements (MGEs) mainly distributed on chromosomes within the Bacillus genus. Pan-genome analysis showed that the 45 genomes contained 554 core genes and many unique genes were dissected in analyzed genomes. Whole genomic alignment showed that Bacillus genus underwent frequently large-scale evolutionary events. In addition, the origin and evolution analysis of $\mathrm{Sb}$ (III)-resistance genes revealed that evolutionary relationships and horizontal gene transfer (HGT) events among the Bacillus genus. The assessment of functionality of heavy metal(loid)s resistance genes emphasized its indispensable roles in the harsh eco-environment of Bacillus genus. The real-time Quantitative PCR (RTqPCR) results of $\mathrm{Sb}(\mathrm{III})$-related genes indicated that the $\mathrm{Sb}$ (III) resistance was constantly increased under the $\mathrm{Sb}$ (III) stress.

Conclusions: The results in this study shed light on the molecular mechanisms of Bacillus sp. S3 coping with Sb(III), extended our understanding on the evolutionary relationship between Bacillus sp. S3 and other closely related species, and further enriched the $\mathrm{Sb}(\mathrm{III})$ resistance genetic data sources.

\section{Background}

The hazardous heavy metal(loid)s, such as antimony (Sb), arsenic (As), cadmium (Cd), chromium (Cr) and lead (Pb) exert a serious threat to the natural environments and human health in many parts of the world [1-3]. In recent decades, natural biogeochemical cycle and anthropogenic activities including mining activities, rapid urbanization, and industrialization have contributed to elevated levels of heavy metal(loid)s in soils [4-5]. Conventional remediation technologies have been developed to remove heavy metal(loid)s from contaminated surroundings, such as ion exchange, membrane separation, coagulation/flocculation, electrochemical methods, extraction and adsorption [6-7]. However, most of these physiochemical remediation methods are not suitable for large-scale applications because of their high cost, generation of secondary pollution and their unsustainable nature [8]. By contrast, microorganism-mediated bioremediation is an alternative promising technology due to its low-cost and environmentally friendly advantages [9]. Microorganisms are able to alleviate the toxicity of heavy metal(loid)s using various resistance strategies, such as extracellular precipitation, intracellular sequestration, enzymatic transformation and oxido-reduction of toxic metal ions $[8,10]$.

Antimony (Sb) is a toxic metalloid in group 15 of the periodic table of elements and excessive Sb can cause harmful damages to the human health $[1,4]$. Sb and its compounds therefore have been listed as priority pollutants by the United States Environmental Protection Agency (USEPA) and the European Union (EU) [7, 11]. The maximum acceptable concentration of $\mathrm{Sb}$ in drinking water has been set at $6 \mu \mathrm{g} / \mathrm{L}$ by the World Health Organization (WHO) [12]. Because it's widely used in flame retardants, $\mathrm{Pb}-\mathrm{Sb}$ alloys, brake linings, and catalysts for polyethylene glycol terephthalate [4, 13], a sharply increasing release of $\mathrm{Sb}$ in the environments occurs during the past decades [1]. The main Sb species include antimonite $[(\mathrm{Sb}(\mathrm{III})]$ and antimonate $[\mathrm{Sb}(\mathrm{V})]$ in soil and water systems, which can be interconverted via biogeochemical processes. $\mathrm{Sb}(\mathrm{V})$ is more stable in aerobic environments than $\mathrm{Sb}$ (III), and $\mathrm{Sb}$ (III) is more toxic than $\mathrm{Sb}(\mathrm{V})$ due to its high 
affinity with thiol-containing proteins [14]. Thus, microbial $\mathrm{Sb}(\mathrm{III})$ oxidation that can transform the toxic $\mathrm{Sb}$ (III) to the less toxic $\mathrm{Sb}(\mathrm{V})$ has a significant value for the environmental $\mathrm{Sb}$ bioremediation [15].

In recently, more than $60 \mathrm{Sb}$ (III)-oxidizing bacteria, including Shinella sp. strain NLS1, Ensifer sp. strain NLS4, Acinetobacter sp. JL7, Comamonas sp. JL25, Comamonas sp. JL40, Comamonas sp. S44, Stenotrophomonas sp. JL9, and Boseasp. AS1 has been isolated from different Sb-contaminated sites $[7,13,14,16]$. Bacillus sp. S3 is a new hyper antimony-oxidizing bacterium, which has been previously isolated from contaminated mine soils [17]. Our previous study confirmed that it exhibited high $\mathrm{Sb}$ (III) oxidation efficiency $\left(50 \mu \mathrm{M} \cdot \mathrm{d}^{-1}\right)$ and $\mathrm{Sb}(\mathrm{III})$ resistance $(5.5 \mathrm{mM})$ [17]. Meanwhile, this bacterial strain has been proved to occupy the ability to cope with multiple heavy metal(loid)s through various adaptive strategies [18]. Although increasing numbers of studies have focused on microbial Sb oxidation, the mechanisms of Sb transformation in Bacillus sp. S3 have not been well characterized so far. Meanwhile, the lack of data on its genome sequence has restricted molecular studies and practical applications.

Furthermore, it is generally noted that Bacillus is a large genus of the gram-positive, heterotrophic, endospore-forming bacteria and belongs to class bacilli, phylum firmicutes [19]. Members of genus Bacillus provide a model system for the study of metal ions and exhibit broad resistance to heavy metals [20]. With the extending of the third-generation sequencing platform PacBio RSII, a large number of the Bacillus strains (more than 4551) have been genomic sequenced. In contrast, there is few literatures on Sb (III) oxidation and resistance mechanisms in genus Bacillus. The arsenite oxidase AioBA responsible for As(III) oxidation in A. tumefaciens 5A was reported to also function as a $\mathrm{Sb}$ (III) oxidase [12]. Moreover, arsenite oxidase AioAB is composed of a large (AioA) and a small (AioB) subunit [21]. A novel $\mathrm{Sb}$ (III) oxidase AnoA was discovered to catalyze $\mathrm{Sb}$ (III) oxidation in A. tumefaciens GW4 with NADP ${ }^{+}$as the co-factor [22], the cellular $\mathrm{H}_{2} \mathrm{O}_{2}$ catalyzed bacterial $\mathrm{Sb}$ (III) oxidation as an abiotic oxidant [23]. Although these studies provide great advance, there has never been a comprehensive research focused on the effects on of $\mathrm{Sb}$ in terms of whole genome and comparative genomics. To further understand the molecular details of Bacillus sp. S3 in response to Sb(III), determination of the genomic information of $\mathrm{Sb}(\mathrm{III})$-resistance strains is crucial. Here, we applied genomes sequence and the comparative genomic analysis to study the Sb resistance mechanism and evolutionary relationship of Bacillus sp. S3.

\section{Methods}

\section{Bacterial strain and culture conditions}

In this study, the bacterial strain of Bacillus sp. S3 was previously isolated from an antimony-mine area, in Hunan province, China [17]. The bacterial cells of Bacillus sp. S3 were aerobically grown in $50 \mathrm{~mL}$ Luria broth (LB) medium (10.0 g/L tryptone, $5.0 \mathrm{~g} / \mathrm{L}$ yeast extract, and $5.0 \mathrm{~g} / \mathrm{L} \mathrm{NaCl}, \mathrm{pH} 7.0-7.2)$ with shaking at $150 \mathrm{rpm}$ at $28 \pm 2{ }^{\circ} \mathrm{C}$. The bacterial growth was measured using ultraviolet-visible spectrophotometer (Shimadzu UV-2550, Japan) by recording optical density at 600 $\mathrm{nm}\left(\mathrm{OD}_{600}\right)$. To determine the hazardous effects of different heavy metal(loid)s on the bacterial growth, different concentrations of $\mathrm{C}_{8} \mathrm{H}_{4} \mathrm{~K}_{2} \mathrm{O}_{12} \mathrm{Sb}_{2} \cdot 3 \mathrm{H}_{2} \mathrm{O}, \mathrm{NaAsO}_{2}, \mathrm{CdCl}_{2}, \mathrm{~K}_{2} \mathrm{CrO}_{4}, \mathrm{PbNO}_{3}, \mathrm{Cu}(\mathrm{SO})_{4}, \mathrm{ZnCl}_{2}$ was added to the culture aliquots [18]. The total concentrations of $\mathrm{Sb}(\mathrm{III}), \mathrm{As}(\mathrm{III}), \mathrm{Cd}(\mathrm{II}), \mathrm{Cr}(\mathrm{VI}), \mathrm{Pb}(\mathrm{II}), \mathrm{Cu}(\mathrm{II})$ and $\mathrm{Zn}(\mathrm{II})$ in each treatment were 100, 1000, 50, $200,500,800$ and $80 \mu \mathrm{M}$, respectively.

\section{Scanning electron microscopy (SEM) and energy dispersive X-ray spectroscopy (EDS) analysis}

Bacterial cells with different metal treatments were firstly harvested in the exponential phase at $4{ }^{\circ} \mathrm{C}$ at $4000 \times \mathrm{g}$ for 10 min when the $\mathrm{OD}_{600}$ reached 0.8 , which were then fixed at $4{ }^{\circ} \mathrm{C}$ in $2.5 \%$ glutaraldehyde for about $2 \mathrm{~h}$. After being

washed twice with phosphate buffer saline (PBS, $0.1 \mathrm{M}$ and pH 7.0) and dehydrated by ethanol (30-100\%) for $20 \mathrm{~min}$, the cells samples were dehydrated using a lyophilizer and coated with a thin layer of platinum via vapor deposition. The surface morphology and property of the Bacillus sp. S3 cell was analyzed using a SEM (Helios NanoLab G3 UC, Thermo 
Fisher Scientific, Czech; accelerating voltage: $15 \mathrm{kV}$ ) equipped with an energy dispersive X-ray analyzer (X-stream-2; Oxford instruments, Oxford, UK).

\section{Whole-genome sequencing, assembly and annotation}

The genomic DNA of Bacillus sp. S3 was extracted using an E.Z.B.A Bacterial DNA Kit (Omega) according to the manufacturer's instructions. The strategy of whole genome sequencing was used a combination of Illumina HiseqXten (Illumina Inc., San Diego, CA, USA) and Pacific Biosciences Sequel sequencing platform (Pacific Biosciences, Menlo Park, CA, USA), and the PE sequence data from the lllumina platform was used to proofread PacBio assembly sequence. Illumina libraries were prepared using NEXTflexTM Rapid DNA-seq Kit (BIOO Scientific Crop., Austin, TX, USA) as recommended by the included instructions. A 10-kb SMRT bell library was prepared from sheared genomic DNA using a 10-kb template barcoded library preparation workflow. Single Molecule Real Time (SMRT) sequencing was conducted on a PacBio Sequel sequencing platform using the SMRT v3.0 cell. For the Bacillus sp. S3 strain, a total of 88,313 clean reads with an average length of 9,904 bp and an N50 size of 13,621 bp were generated (Table S1-3).

De novo assembly of the PacBio read sequences was performed using continuous long reads (CLR) following the Hierarchical Genome Assembly Process (HGAP4) workflow (PacBioDevNet; Pacific Biosciences) as available in SMRT Link [24]. HGAP 4 consists of preassembly, de novo assembly with Celera Assembler, and assembly polishing with Quiver. To improve the accuracy of the assembly genome, four rounds of iterative error correction were carried out using the illumina clean data by in house script. The final assembly generated a circular genome sequence with gapless.

Protein-coding regions in the assembled sequences were predicted using Prodigal [25]. tRNA and rRNA were separately identified by tRNA-scan and RNAmmer, respectively [25]. Genome annotation was carried out by a command line software tool: rapid prokaryotic genome annotation (Prokka) [26]. The genes functions were determined against the NCBI nonredundant (NR), Gene Ontology (GO), Clusters of Orthologous Groups (COG), and Kyoto Encyclopedia of Genes and Genomes (KEGG) databases with E-value cut-off set to $1 \mathrm{e}^{-5}$ and subsequent filtering for the best hit [27].

\section{Phylogenetic analysis and average nucleotide identity (ANI)}

To perform the comparative analysis, 44 most closely related species and representative species were retrieved from the GenBank database by BLASTP search (Table 2). Three different datasets of representative markers, 16S rRNA sequences, core genes and whole genomes were used to construct phylogenetic trees. The phylogenetic tree of Bacillus sp. S3 based on the 16S rRNA gene sequences was constructed using the NJ method in MEGA v7.0 with 1,000 bootstraps replications [28]. Phylogeny based on only one common gene may result in bias; therefore, we constructed the phylogenetic tree based on the core genes, which were shared by the comparative strains (see 'Comparative genomics'). The core genes of the 44 Bacillus strains were fetched by Bacterial Pan Genome Analysis (BPGA) software [29]. The multiple sequences alignment of copy core genes was performed using MUSCLE software [30] and the phylogenetic tree was generated using the NJ method in MEGA v7.0 with 1,000 bootstraps replications. In addition, the phylogenetic tree based on whole-genomes of Bacillus strains was also constructed in our study, in which Paenibacillus sp. Y412MC10 strain was designed as an outgroup [31]. The average nucleotide identity (ANI) values between the newly sequenced Bacillus sp. S3 genomes and the representative genomes of Bacillus spp. were calculated using the web server JSpecies1.2.1 [32] based on a BLAST algorithm and tetranucleotide frequency correlation coefficient (Tetra) with default parameters [33]. In addition, the DNADNA hybridization (DDH) values were calculated using Genome-to-Genome Distance Calculator [34].

\section{Comparative genomics analysis}

Bacterial Pan Genome Analysis tool (BPGA) was used to extrapolate pipeline pan-genome models with default parameters, and all of orthologous groups among testing genus Bacillus were identified [29]. The core genome is the common set of shared genes among all testing strains, the pan-genome is the entire set of genes within test genomes, the accessory 
genome is the set of genes shared with more than two but not all testing strains and unique genes is the set of genes in each strain not shared with other strains [27]. The details of the strains used were listed in Table 2. Furthermore, synteny maps were generated to unravel the degree of rearrangements (insertions, deletions, duplications) by identifying conserved locally collinear blocks (LCBs) among genomes. Multiple alignment of closely related genomes was also performed using the Mauve Genome Alignment v2.3.1 with the progressive Mauve algorithm [35].

\section{Genes for heavy metal(loid)s resistance}

The genes related to the resistance of $\mathrm{Sb}$ (III) and other heavy metal(loid)s in the Bacillus sp. S3 genome and other comparative Bacillus genomes were identified by performing BLASTP searches against the BacMet database [36]. Subsequently, each $\mathrm{Sb}$ (III) resistance gene was compared on NCBI database to find these genes of high similarity. Finally, the evolutionary history of genes related to $\mathrm{Sb}$ (III) was inferred using the $\mathrm{NJ}$, the maximum likelihood (ML), and UPGMA methods in MEGA v7.0 with 1,000 bootstraps [5].

\section{Prediction of mobile genetic elements (MGEs)}

Genomic islands (GIs) were detected using the web server IslandViewer $4^{8}$ with three prediction methods, including IslandPath-DIMOB, SIGI-HMM, and IslandPick with default parameters [37]. Insertion sequences (ISs) were predicted and classified using the ISFinder platform against the ISfinder database with default criteria [38]. CRISPR arrays were detected using the CRISPR Finder online server to perform BLAST searches against dbCRISPR (CRISPR database) [39]. PHAST [40] was used to scan prophages by BLASTing against the NCBI and the prophage databases.

\section{Selective pressure analysis and expressivity prediction}

The CAI (codon adaptation index) values of selected genes were analyzed using Codon W1.4.2

(http://codonw.sourceforge.net//) and CAI Calculator 2 (http://www.evolvingcode.net/codon/CalculateCAls.php). The mode and strength of natural selection in protein sequences was estimated by evaluated the ratio of nonsynonymous ( $d N$ ) to synonymous $(d S)$ nucleotide substitutions rates by using the online software Datamonkey, and the HyPhy package with Single-Likelihood Ancestor Counting method was used to detect the selection sites [41].

\section{Quantitative real-time PCR (qRT-PCR)}

When Bacillus sp. S3 growth reached middle exponential phase, culture aliquots were amended with 0, 100, 200 and 300 $\mu \mathrm{M}$ of $\mathrm{Sb}(\mathrm{III})$, respectively. The culture aliquots were withdrawn at different time intervals $(0.5,1,2$ and $4 \mathrm{~h})$ and cells were harvested by centrifugation at $4,000 \times \mathrm{g}$ for $10 \mathrm{~min}$ at $4{ }^{\circ} \mathrm{C}$. After quick freezing in liquid nitrogen, the total RNA of each sample was isolated and purified using the E.Z.B.A Bacterial RNA Kit (Omega) (Zoman, Beijing, American) according to the manufacturer's instructions. The concentration of RNA was measured at the $A_{260 / 280}$ ratio using a NanoDrop ND-1000 Spectrophotometer (BioTek Instruments, Inc, Vermont, USA) and the integrity of the sample was determined by $1.0 \%$ agarose gel electrophoresis. First-strand cDNA was synthesized with $2 \mathrm{mg}$ of total RNA in a $20 \mathrm{~mL}$ total reaction volume using the 5xHiScriptll qRT SuperMixll (Vazyme Biotech Co., Ltd, China). Quantitative real time polymerase chain reaction (qRT-PCR) analyses was performed using iCycler iQ Real-time PCR detection system (Bio-Rad Laboratories, Inc., Hercules, USA) with a $20 \mathrm{~mL}$ reaction volume and using $2 \times$ ChamQ $^{T M}$ Universal SYBR qPCR Master Mix (Vazyme Biotech Co., Ltd, China). Primers were designed by using Primer Premier 5 software (Table S9) [19]. Gene expression was calculated by $2^{-}$

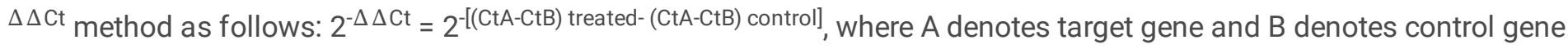
[22].

\section{Statistical analysis}


All experiments were expressed as mean \pm standard deviation (SD) of the triplicate. Statistical analysis was carried out by one-way ANOVA followed by post-hoc test-Tukey's test $(p<0.05)$ in SPSS version 21.0 (SPSS Inc., Chicago, IL, USA).

\section{Data availability}

The genome and plasmid sequences of Bacillus sp. S3 were deposited in the NCBI GenBank under the accession numbers CP039727.1 and CP039728.1., respectively.

\section{Results And Discussion}

\section{Characteristics of Bacillus sp. S3 with different heavy metal(loid)s}

In the previous study, Bacillus sp. S3 showed high tolerance to multiple heavy metal(loid)s [18]. As shown in Fig.1, the SEM images of Bacillus sp. S3 intuitively showed that the cell walls were enveloped by filaments, possibly as a result of the presence of extracellular polymeric substances. Intriguingly, after cultivation of Bacillus sp. S3 for exponential phase under the $\mathrm{Sb}$ (III) stress, the cell surface became smoother than control. As shown in Fig. S1, no physical Sb(III) adsorption was detected on Bacillus sp. S3 cell surfaces by EDS analysis, the result is kind of other studies [9]. When the initial concentration was $1 \mathrm{mM} \mathrm{Pb}(\mathrm{II})$, the peak value of EDS was significant from that of the control group and other treatment groups. The SEM results showed that smaller cell size, lesser wrinkled cell wall and the occurrence of intracellular dissolution in present of heavy metal(loid), implying that the elevated levels of heavy metal(loid) ions might suppress the secretion of extracellular polymers substance and normal metabolism. The smallness of bacterial cells provided a large contact interface, which would facilitate the interaction between heavy metal(loid)s and biosorption process of Bacillus sp. S3. The EDS spectra results revealed that Bacillus sp. S3 might further absorb $\mathrm{Pb}$ (II) to a certain extent compared with other heavy metal(loid)s, such as extracellular adsorption and surface complexation [9].

\section{General genome feature of Bacillus sp. S3}

The general genomic features of Bacillus sp. S3 were summarized in Table 1 and Fig. 2. The whole genome of Bacillus sp. S3 contained one single circular chromosome of 5,579,638 bp with $40.30 \%$ GC content and one plasmid of 241,339 bp with $36.74 \%$ GC content (Fig. 2A, B). The whole genome harbored 5,131 protein-coding sequences covering $85.35 \%$ of the genome with the average length of $904 \mathrm{bp}$, as well as 36 rRNAs and 104 tRNAs (Table 1). In addition, the genomic features of Bacillus sp. S3 and the other 44 closely related strains were summarized in Table 2. The average chromosome length of the 45 Bacillus genomes is $4.99 \mathrm{Mb}$ with ranging from 2.2 to $7.08 \mathrm{Mb}$ and the average $\mathrm{GC}$ content was $40.31 \%$ with ranging from $35.4 \%$ to $47.8 \%$, indicating substantial species-to-species or strain-to-strain variations and similar genomic characteristics. Among these investigated strains, Bacillus sp. OxB-1 showed the highest GC content (47.8\%), and $B$. thuringiensis and B. cereus SJ1 showed lower GC contents (35.4\%).

Based on BLASTP searches (e value $<1 \mathrm{e}^{-5}$ ), there were 4371 and 2564 CDSs involved in COG database (Fig. S2, Table S4) and GO database, respectively (Fig. S3, Table S5). A high proportion of genes in COG database were assigned to the general function prediction only $(R, 10.3 \%)$, amino acid transport and metabolism ( $E, 8.05 \%)$, carbohydrate transport and metabolism (G, 6.15\%), energy production and conversion (C, 5.33\%), transcription (K, 5.06\%), and replication, recombination, and repair $(\mathrm{L}, 4.6 \%)$ categories. In addition, the proteins were distributed to $\mathrm{GO}$ database in three functional classification, including "molecular function" (2715), "cellular component" (1001) and "biological process" (3615). Compared to other bacteria, enrichment profiles of Bacillus sp. S3 genes assigned to COG functional categories showed an overabundance of genes involved in amino transport and metabolism, carbohydrate transport and metabolism, energy production and conversion. These resistance genes involved in defense and repair mechanisms for dealing with heavy metals propelled by harsh eco-environments, such as nitrate and heavy metals [10]. These resistance genes include $A B C$ antiporters and $\mathrm{Cd}^{2+} / \mathrm{Zn}^{2+} / \mathrm{Co}^{2+}$ efflux components (CzcABC, CzcD) were probably important for Bacillus sp. S3 in the adaption of specific niche. 
In addition, the KEGG pathway database was used to map their corresponding terms on the Bacillus sp. S3 genome. A total of 3691 CDSs were assigned to 180 KEGG pathways (Fig. S4, Table S6), which could enriched in "Metabolism" (637), "Biosynthesis of secondary metabolites" (285), "Microbial metabolism in diverse environments" (215), "Carbon metabolism" (135), "Biosynthesis of amino acids" (134) and "ABC transporters" (122). The arsenite oxidase (AioB) was assigned to metabolic pathway (ko01100), the phosphate-binding protein (PstS), sn-glycerol-3-phosphate-binding periplasmic protein (UgpB) and phosphate import ATP-binding protein (PstB) were assigned to ABC transporters pathway (ko02010), the copper-ion-binding protein CopZ was assigned to mineral absorption pathways (ko04978), these pathways may play an important role in response to the metal(loid) toxicity.

As shown in Fig. S5, we identified 237 carbohydrate-active enzymes (CAZymes) in the genome of Bacillus sp. S3. Predicted CAZymes were classified into 6 classes, encompassing auxiliary activities (AAs, 4), carbohydrate-binding modules (CBM, 63) carbohydrate esterases (CEs, 39), glycoside hydrolases (GHs, 90), glycosyltransferases (GTs, 39), polysaccharide lyases(PLs, 2).To induce inhibition, the heavy metal(loid) ions might non-specifically bind to regions of CAZymes [42].This interactions between heavy metal(loid)s and CAZymes need a great deal of energy (e.g. for pumping out intracellular metal ions by ATPases, or for the strengthened expression of metal(loid) resistance proteins, etc.) through increased conversion of carbohydrates [43]. It implied that these enzymes might play an important role in coping with the metal(loid) ions [42].

Notably, large numbers of heavy metal(loid) resistance genes were found to locate on the chromosome rather than plasmid in Bacillus sp. S3 (Table 3), which could be used for further analysis of genetic diversity and evolutionary. Unlike chromosome, the plasmid was found to contain a large number of hypothetical proteins. The aioAB genes encoding As(III) oxidase were responsible for $\mathrm{Sb}(\mathrm{III}) / \mathrm{As}$ (III) oxidation, which could convert the more toxic $\mathrm{Sb}$ (III) to the less toxic $\mathrm{Sb}(\mathrm{V})$ in the periplasm [12]. In our study, the $a i o B$ gene was only detected in the chromosome of Bacillus sp. S3 but not the other Bacillus genomes, giving Bacillus sp. S3 the capacity to oxidize Sb(III). Moreover, our data showed that cytoplasmic Sb(III) extrusion was the main As/Sb resistance strategy in Bacillus genus. As resistance genes (ars $B$ and ars $C$ ) were detected in all comparative Bacillus strains. Three arsB genes encoding $\mathrm{Sb}$ (III)/As(III) efflux pump membrane proteins and ars $C$ gene encoding $\mathrm{As}(\mathrm{V})$ reductase were located on the chromosome in Bacillus sp. S3. The phosphate (Pi) related genes, such as phoB, pstS, and phoR, were also identified in Bacillus sp. S3, which have been proved to be co-regulated with As(III) oxidation and could be induced by $\mathrm{Sb}(\mathrm{III})$ in previous report [44].

\section{Phylogenetic analyses}

To evaluate the phylogenetic relationship, we downloaded 44 Bacillus genome sequences (including 16 complete genomes) and their annotations from the NCBI GenBank database (Table 2). The phylogenetic tree based on 16S rRNA gene sequences revealed that Bacillus sp. S3 belonged to Bacillus genus and grouped with other Bacillus sp. L75, Bacillus soil strain G8 and Bacillus drentensis G18 (Fig. 3A). Although 16S rRNA gene has been conventionally been used for assessing bacterial taxonomy and phylogeny, there was still controversy and uncertainty based on only one gene [45]. The phylogenetic trees based on 554 core genes and whole-genome composition vectors (CVs) were also constructed (Fig. 3B, C). In the two phylogenetic trees, Bacillus sp. S3 was most closely related to the Bacillus bataviensis. However, the topologies of the two phylogenetic trees exhibited some differences, suggesting that the flexible genes could be crucial in altering the genome content and shaping the topology of the trees.

ANI is the most widely accepted bioinformatics tool that evaluate the genomic distance and delineate species in evolutionary progress, overcoming the difficulty of conventional deviations caused by evolutionary mutation rate and HGT events [32]. As show in Table 3, the closest ANI values $81.51 \%$ between Bacillus sp. S3 and other reference strains considerably lower than threshold value of $95-96 \%$ of the boundary for species circumscription [46]. Besides, the value of $70 \% \mathrm{dDDH}$ was the recommended standard for species delineation of bacteria, corresponding tightly to $95 \%$ ANI [47]. The 
results showed that the dDDH\% values of Bacillus sp. S3 against all reference genomes ranging from $12.7 \%$ to $34 \%$ (Table S7). Thus, the results of ANI and dDDH values indicated that Bacillus sp. S3 represented a novel species.

\section{Core and pan genomes analysis}

To clarify the genomic features specific to each Bacillus strain, all genes from tested Bacillus strains were described by MP method in the pan-genome analysis pipeline with a $50 \%$ cut-off for protein sequence identity. There were total 39,933 orthologs protein coding sequences in the pan genome for the Bacillus genus (Fig. 4A). Of these orthologs genes, 554 (1.38\% of total pan genome) were identified as core conserved genes, and 16,234 were identified as strain-specific genes. Accessory gene number varied from 1,189 to 4,431 (mean 3,693) and the isolated Bacillus sp. S3 had 3,893 accessory gene. Accessory gene is known as indispensable orthologs, the variability of accessory gene indicating the flexibility of genome structure [48]. After comparing strain-specific genes, the variability in the total number of strain-specific genes ranges from 0 to 1560 genes (mean 360). Bacillus sp. OxB-1 had the highest amount of these $(n=1560)$, reflecting the greatest difference with other tested genomes.

Previous reports stated that a mathematical extrapolation of the pangenome was highly remarkably reliable when sufficient genomes $(>5)$ were involved [49]. The deduced power law regression function $\left[P_{s}(n)=5313.92 n^{0.527477}\right]$ revealed that the pan-genome of Bacillus had a parameter $(\gamma)$ of $0.527477(0<\gamma<1)$, implying a stabilized core structure and an open pan-genome of Bacillus strains (Fig. 4B). Thus, the new orthologs were intuitively observed after addition of more genomes to the group. Furthermore, the extrapolated curve of the core genome presented a steep slope according to the exponential regression $\left[F_{c}(n)=1779.45 \mathrm{e}^{-0.0387412 n}\right]$ (Fig. 4B). The addition of an extra genome would not significantly alter the size of the core genome due to the numbers of core genes were relatively constant [43].

These core genes shared with all Bacillus genomes also could be classified into different COG categories (Fig. 4C), which was agreed with previous reports that larger prokaryotic genomes tended to pile up genes directly or indirectly involved in different metabolism [50]. The KEGG annotation of 385 specific genes of Bacillus sp. S3 showed that 10 genes involved in the environmental information processing, including one cobalt transport system protein-encoding gene cor $A$ and one As(III) efflux pump membrane proteins-encoding gene arsB. Further, small number of strain-specific genes (<40\%) were assigned to the COG categories for the Bacillus sp. S3, which were mainly found to be enriched in phosphotransferase ABC-type metal ion transport systems. The result revealed specific adaptive strategies for Bacillus sp. S3 in response to harsh eco-environment.

\section{Mobile gene elements in Bacillus genomes}

It is well recognized that bacteria genomes have notable genome plasticity by several elements of HGT events, known as mobile gene elements (GEls, IS, Prophages) and CRISPRs [51]. The presence of the majority of GEls in Bacillus sp. S3 and other comparative strains renders clues about the genomic plasticity of these isolates (Table S8). We identified 20/5/15 GEls in Bacillus sp. S3 through three methods. These GEls were possibly conducive to the integrated pool of transposase. Analysis of transposable elements showed that numerous insertion sequence (IS) elements were distributed over the genomes and plasmids of Bacillus strains, harboring IS1, IS2, IS3, IS4, IS5, IS21 and IS256. The numbers of insertion sequence (IS) elements could magnify the size of genome, and result in frequently genomic exchange with other community members [51].

As shown in Table S8, all Bacillus genomes could be served as feasible targets of phage infections. A total of 5 intact ( $100 \%$ score) prophage regions were predicted in the genome of Bacillus sp. S3, their information containing size: 11485 bp, 5841 bp, 8630 bp, 8468 bp, 7959 bp; coding sequence: 11, 7, 6, 10, 8; GC content: 42.84\%, 38.02\%, 35.25\%, 36.25\%, $33.84 \%$ (Figure S6). It is interesting noted that the number of CRISPRs varied between 0 and 15 per strain and CRISPR loci absolutely scattered the chromosome. 4 confirmed CRISPR with 39, 20, 60, 4 spacers were detected in Bacillus sp. S3. Our 
findings suggested that the Bacillus genus could trigger various defense mechanisms against the invasion of exogenous DNA for maintaining the stability of their genetic architecture during the evolution.

Signatures of HGT events generally could be facilitated by MGEs, such as integration sites, anomalous GC contents, or varied codon usage, suggesting that the potential contributor of the observed genomic rearrangements between the genomes of genus Bacillus [51]. MGEs were key driving forces of genome evolution [11], indicating that high genomic plasticity in Bacillus genus was extended to potential strategies to cope with high metal(loid) ion concentrations of their natural habitats. Genomic island (GEls), which have been committed to provide antibiotic resistance to the host bacteria, were generally divided into 4 categories based on their function, including resistance island (RIs), virulence genes, metabolic islands, and symbiotic island(SIs) [52]. These islands promoted symbiotic integration of the host with other microorganisms [53]. CRISPR-Cas system is a type of adaptive immunity in bacteria and archaea, which protect them against invading genetic elements [54]. Bacillus sp. S3 might acquire specific functional gene clusters related metal(loid)s from other genera via HGT and genomic reshuffling, which was integrated into its genome and enhanced the adaptability of coping with heavy metal(loid)s.

\section{Comparative genomic analysis of Bacillus genus}

Mauve has been used for constructing multiple genome alignments in large-scale evolutionary events such as genome rearrangement, inversion, and other recombination [55]. To prove the extent of genomic shuffling, the whole genome sequence of Bacillus sp. S3 was compared individually with the other 10 complete genomes using mauve with default settings. As shown in Fig. 5, synteny maps of the 10 complete genomes were inspected, and represented large-scale blocks of inversions and several crisscrossing locally collinear blocks (LCBs). 615 LCBs with a minimum weight of 45 were exhibited between Bacillus sp. S3 and B. bataviensis LMG21833, other comparative information was also observed. Mauve analyses showed Bacillus sp. S3 had the highest synteny with B. bataviensis LMG21833 genome, other strains exhibited more number of rearrangement, insertion, and deletions. These results revealed that conserved structural synteny and lack of inversions and rearrangements were observed among members of Bacillus group, suggesting that the largescale evolutionary events were occurred at the genus level $[24,56]$. This was in agreement with genome distance in phylogenetic tree.

\section{The origin and evolution of heavy $\mathrm{Sb}(\mathrm{III})$-related genes}

To examine the origin and evolution of $\mathrm{Sb}$ (III)-related genes in Bacillus sp. S3, including aioB, arsB and arsC, these genes that contribute to $\mathrm{Sb}$ (III) resistance of Bacillus genus were selected. Genome evolution could be driven by the acquisition and loss of genes, which was conducted by HGT, genomic reshuffling and natural selection [57]. Comprehensive analysis of HGT events was performed, since it was difficult to identify via either phylogenetic analysis or deviant $\mathrm{G}+\mathrm{C}$ content. The deviant $\mathrm{G}+\mathrm{C}$ content between gene and the genome could be used as a detection method of HGT [46]. Herein, we detected the $\mathrm{G}+\mathrm{C}$ contents of $\mathrm{Sb}(\mathrm{III})$-related genes and their corresponding genomes in Bacillus strains. It is worth noting that the aioB gene was specific gene of Bacillus sp. S3, whose GC content was significantly higher than that of the genome (44.64 vs. 40.3). As shown in Fig. S7, the average GC contents of the Sb(III)-related genes were different from that of their corresponding genomes in Bacillus strains.

The overall origin and evolution of $\mathrm{Sb}(\mathrm{III})$-related genes in Bacillus genus were inferred by phylogenetic trees with NJ, ML and UPGMA methods. We speculated that the $a i o B$ gene in Bacillus sp. S3 derived from the evolution of $2 \mathrm{Fe}-2 \mathrm{~S}$ ferredoxin (Fig. S8-10). To further elucidate the evolution of $\operatorname{ars} B$ cluster/ ars $C$, phylogenetic trees based on ArsB and ArsC proteins were constructed. The results showed that arsB clusters of Bacillus sp. S3 formed separate 3 groups and a monophyletic clade, suggesting that the ars $B$ cluster/ars $C$ of Bacillus sp. S3 may originate from a common ancestor with $B$. bataviensis LMG21833 (Fig. S11-16). Bacillus sp. S3 likely obtained arsB cluster from B. bataviensis LMG21833, $B$. vireti and $B$. drentensis, since prosperus branch of arsB cluster of Bacillus sp. S3 near the base of the clade (Fig. S11-13). As shown in 
Fig. S14-16, the arsC gene of Bacillus drentensis may be acquired via HGT events from Rhodococcus qingshengii. The results showed that Bacillus sp. S3 acquired As/Sb resistance genes via HGT. These data suggested that the As/Sb resistance genes were horizontally transferred between the Bacillus sp. S3 and other species. The results were found to be consistent with previous reports, such as bacterial As resistance and detoxification acquired via HGT [58].

\section{Assessment of functionality of heavy metal(loid)s-related genes}

Previous reports showed that the CAI was a numerical estimator of gene expression level, due to highly expressed genes in bacteria were prone to magnify stronger codon bias [59]. The CAI value varies from 0 to 1.0, with higher CAI value indicating a higher expression level [60]. In order to indirectly assess the functionality of metal(loid) resistance genes, the appraisal of the strength of natural selection was performed, along with the CAls of these genes. Putative highly expressed (PHX) genes associated to metal(loid) resistance in the Bacillus genus were inferred, where gerd gene encoding spore germination protein was used as a reference. As shown in Fig. 6A, the CAl values of these above-mentioned metal(loid)s resistance genes were calculated. The cutoff values were indicated with average CAI values of Gerd genes in each species. Our result showed that only about $8 \%$ of the metal(loid) resistance genes were predicted to be PHX genes that greater than 0.75 , while lots of genes had CAl values range from 0.4 to 0.8 . The PHX genes lead to stronger codon bias than those of low expressed level genes, resulting from codon translational selection.

A gene in the node or tip of a given tree was considered under diversifying selection $(d N / d S>1)$, evolving neutrally $(d N / d S$ $\approx 1)$ or purifying selection $(d N / d S<1)$ using the likelihood ratio test after adjusting for multiple testing $(\mathrm{P}$ value $<0.1)$. As shown in Fig. 6B, 96.3\% of 10 selected genes associated metal(loid) had a ratio of nonsynonymous substitutions $(d N / d S<1)$, implying that these genes were indispensable factor for the above-mentioned Bacillus species under the pressure of purifying selection. Only an ars $C$ gene from $B$. bataviensis $L M G 21833(d N / d S=1.63)$, double chrA genes from B. niacin DSM 2923 and $B$. liceniformis ATCC 14580 ( $d N / d S=2.08, d N / d S=1.28$ ), a copZ gene from $B$. firmus NCTC 10335 $(d N / d S=1.28)$, a corA gene from Bacillus sp. LF1 $(d N / d S=2.80)$, double znuB genes from $B$. soli 15604 and $B$. bataviensis LMG21833 $(d N / d S=2.02, d N / d S=1.1)$ showed that $d N / d S>1$, suggesting that they might be under diversifying selection. Furthermore, the lowest $d N / d S$ ratio was remarked for $\operatorname{cop} A$ gene (average $d N / d S=0.08$ ) and the zur gene (average $d N / d S=0.09$ ), demonstrating strong purifying selection. Additionally, these genes including ars $B$ from Bacillus mesonae $\mathrm{H} 20-5$, chrR from Bacillus mesonae H20-5 and Bacillus sp. S3, copZ from B. thuringiensis 97-27, Bacillus glycinifermentans BGLY and B. oceanisediminis strain Bhandara28, corA from B. firmus strain 14_TX, showed $d N / d S$ ratio $=1.0$, indicating that selection force had little effect on them. These results showed that metal(loid) resistance genes had universally low $d N / d S$ ratios and high CAI values, indicating that their functions play a role in supporting the growth of Bacillus species in response to harsh environments [60].

\section{Transcriptional expression analysis in Bacillus sp. S3 with or without Sb(III)}

To gain the insights into the role of Bacillus sp. S3-specific genes annotated as "arsenate oxidase (aio)" and "protein of resistance function (ars)" in presence of $\mathrm{Sb}(\mathrm{III})$, the expression levels of aioB, arsB_123, ars $C$ and psts_ 1 was investigated by qRT-PCR. Primers used in the study are listed in Table S9, where 16S rRNA gene was used as an internal reference. As shown in Fig. 7, the results showed that the transcriptional expression levels of most of genes were up-regulated induced by $\mathrm{Sb}$ (III) except for ars $C$. Although the exposure of $0.5 \mathrm{~h} \mathrm{Sb}$ (III) decreased the transcriptional expression levels of ars $B_{-} 123$ and $\operatorname{ars} B$ cluster, the expression levels of $\operatorname{aio} B$ and $a r s B_{-} 123$ were up-regulated after $1 \mathrm{~h}, 2 \mathrm{~h}$ and $4 \mathrm{~h}$. The expression levels of aioB gene was $15.8,4.4$, 2.6-fold change higher with $100 \mu \mathrm{M} \mathrm{Sb}$ (III) from 1 to 4 h compared to uninduced culture. Nevertheless, when the Bacillus sp. S3 was exposed to high Sb(III) concentration (200 and $300 \mu \mathrm{M})$, the expression level of aio $B$ gene was up-regulated 2.6, 2.1, 1.3 and 2.5, 2.8, 2.1 fold changes from 1 to $4 \mathrm{~h}$. Thus, the expression level of aioB had nothing to do with the concentration and stress time of $\mathrm{Sb}(\mathrm{III})$. In addition, the expression levels of ars $B_{-} 123$ ( $2 \mathrm{~h}$ and $4 \mathrm{~h}$ ) were remarkably up-regulated. The expression levels of $a r s B_{-} 123$ and psts_ 1 were up-regulated along with increasing the $\mathrm{Sb}$ (III) concentration. The increased expression levels of $a i o B$ and ars $B_{-} 123$ in the presence of $\mathrm{Sb}$ (III) suggested that $\mathrm{Sb}$ (III) 
could stimulate the expression levels of $\mathrm{As}(\mathrm{III}) / \mathrm{Sb}$ (III) resistance genes, which might act synergistically to release the toxicity of $\mathrm{Sb}(\mathrm{III})$ in Bacillus sp. S3.

It has been reported that aioA expression was induced by $\mathrm{Sb}(\mathrm{III})$ [11]. Our results showed that expression level of aioB was up-regulated from 1 to $4 \mathrm{~h}$ compared to uninduced cell, indicating that the aio $B$ gene was induced by $\mathrm{Sb}$ (III) and played a putative part in oxidizing $\mathrm{Sb}(\mathrm{III})$. Nevertheless, $0.5 \mathrm{~h} \mathrm{Sb}$ (III) exposure suggested that the expression level of aio $B$ gene was not up-regulated during the earlier time points. It is noteworthy that the expression level of aioB in higher $\mathrm{Sb}$ (III) concentration (200 and $300 \mu \mathrm{M})$ notably lower than $100 \mu \mathrm{M} \mathrm{Sb}(\mathrm{III})$, indicating that the higher Sb(III) concentration could inhabit aioB expression. These results were basically consistent with the previous reports that the excessive As(III) treatment could inhibit the $a i o B$ expression [12]. In addition, the expression level of psts_ 1 gene involved in phosphate metabolism and co-regulated the aioBA genes was induced by $\mathrm{Sb}(\mathrm{III})$, suggesting that Bacillus sp. S3 required the DNA repair and amino acids synthesis processes in response to $\mathrm{Sb}$ (III) by enhancing production of $\mathrm{Pi}$ and phosphoribosyl pyrophosphate [22].

\section{Conclusion}

In this study, we sequenced a hyper $\mathrm{Sb}$ (III) oxidation strain Bacillus sp.S3 and performed comparative genomic study of the Bacillus group, representing substantial improvements over previously published results. The majority of genes encoding metal(loid) resistance proteins and MGEs were discovered in Bacillus sp.S3, which could adapt to a metal(loid)contaminated environment. Meanwhile, there was an arsenate oxidase AioB in the Bacillus sp. S3, which could play a key role in the process of $\mathrm{Sb}$ (III)-oxidizing. Notably, Bacillus sp. S3 was identified as a new species by phylogenetic trees and ANI analysis. In addition, $6 \mathrm{Sb}$ (III)-related genes in the Bacillus sp. S3 were all induced Sb(III) using RT-qPCR, indicating these genes occupied a significant position in alleviating the toxicity of $\mathrm{Sb}$ (III). The comparative genome of the 45 Bacillus species and origins and evolution of $\mathrm{Sb}$ (III)-resistance genes were explored. This finding could improve our understanding of the genomic characteristics and evolutionary relationship among the Bacillus genus. As a consequence of the lack of comprehensive analysis with respect to genetic expression and regulation by Bacillus sp. S3, the molecular basis of microorganism-Sb(III) needs further clarify in the near future via gene knockouts and protein characterization.

\section{Abbreviations}

$\mathrm{Sb}$ (III): antimonite; As(III): arsenite; ANI: Average nucleotide identity; NCBI: National center for biotechnology information; dDDH: digital DNA-DNA hybridization; LCB: locally collinear block; ML: Maximum likelihood; MGE: Mobile genetic element; $\mathrm{NJ}$ : neighbor-joining; CDSs: protein-coding genes.

\section{Declarations}

\section{Acknowledgements}

We gratefully acknowledge the Institute of Microbiology, Chinese Academy of Sciences (Beijing, China) providing the Pacific Biosciences (PacBio) RSII. We would like to thank Chenbing Ai, Xiaoyan Wu, Na Lv, and Fei Liu for their research assistance.

\section{Funding}

This work was supported by the National Natural Science Foundation of China (No. 31470230, 51320105006, 51604308), Key Research and Development Projects in Hunan Province (2018WK2012), Natural Science Foundation of Hunan 
Province of China (No.2018JJ2486), the Youth Talent Foundation of Hunan Province of China(No.2017RS3003),

Fundamental Research Funds for the Central University of Central South University (No. 2019zzts687).

\section{Availability of date and materials}

All sequences involved in this study are available from the DDBJ/ENA/GenBank under accession number CP039727 and CP039728, respectively.

\section{Authors' contributions}

TG analyzed the date and wrote the manuscript. LL and LJ assisted in data analysis and revised the manuscript. LJ, YR, and ZW conceived the project. SL, LW and WX helped revised the manuscript. All authors discussed the manuscript draft and agreed to the final content.

\section{Ethics approval and consent to participate}

Not applicable.

\section{Consent for publication}

Not applicable.

\section{Competing interests}

The authors declare no competing financial interest.

\section{References}

1. He M, Wang X, Wu F, Fu Z. Antimony pollution in China. Sci Total Environ. 2012;421:41-50.

2. Guo H, Luo S, Chen L, Xiao X, Xi Q, Wei W, et al. Bioremediation of heavy metals by growing hyperaccumulaor endophytic bacterium Bacillus sp. L14. Bioresour Technol. 2010;101:8599-605.

3. Nguyen TA, Ngo HH, Guo WS, Zhang J, Liang S, Yue QY, et al. Applicability of agricultural waste and by-products for adsorptive removal of heavy metals from wastewater. Bioresour Technol. 2013;148:574-85.

4. Herath I, Vithanage M, Bundschuh J. Antimony as a global dilemma: geochemistry, mobility, fate and transport. Environ Pollut. 2017;223:545-59.

5. Li L, Liu Z, Meng D, Liu X, Li X, Zhang M, et al. Comparative genomic analysis reveals the distribution, organization, and evolution of metal resistance genes in the genus Acidithiobacillus. Appl Environ Microbiol. 2019;85:e02153-18.

6. Rajesh V, Kumar ASK, Rajesh N. Biosorption of cadmium using a novel bacterium isolated from an electronic industry effluent. Chem Eng J. 2014;235:176-85.

7. Nguyen VK, Choi W, Yu J, Lee T. Microbial oxidation of antimonite and arsenite by bacteria isolated from antimonycontaminated soils. Int J Hydrogen Energ. 2017;42:27832-42. 
8. Ma Y, Rajkumar M, Zhang C, Freitas H. Beneficial role of bacterial endophytes in heavy metal phytoremediation. J Environ Manage. 2016;174:14-25.

9. He M, Li X, Liu H, Miller SJ, Wang G, Rensing C. Characterization and genomic analysis of a highly chromate resistant and reducing bacterial strain Lysinibacillus fusiformis ZC1. J Hazard Mater. 2011;185:682-8.

10. Hemme CL, Deng Y, Gentry TJ, Fields MW, Wu L, Barua S, et al. Metagenomic insights into evolution of a heavy metalcontaminated groundwater microbial community. ISME J. 2010;4:660.

11. Li J, Yang B, Shi M, Yuan K, Guo W, Li M, et al. Effects upon metabolic pathways and energy production by Sb(III) and As(III)/Sb(III)-oxidase gene aioA in Agrobacterium tumefaciens GW4. PloS one. 2017;12:e0172823.

12. Wang Q, Warelow TP, Kang YS, Romano C, Osborne TH, Lehr CR, et al. Arsenite oxidase also functions as an antimonite oxidase. Appl Environ Microbiol. 2015;81:1959-65.

13. Lu X, Zhang Y, Liu C, Liu C, Wu M, Wang H. Characterization of the antimonite-and arsenite-oxidizing bacterium Bosea sp. AS-1 and its potential application in arsenic removal. J Hazard Mater. 2018;359:527-34.

14. Li J, Wang Q, Zhang S, Qin D, Wang G. Phylogenetic and genome analyses of antimony-oxidizing bacteria isolated from antimony mined soil. Int Biodeter Biodegr. 2013;76:76-80.

15. Terry LR, Kulp TR, Wiatrowski H, Miller LG, Oremland RS. Microbiological oxidation of antimony(III) with oxygen or nitrate by bacteria isolated from contaminated mine sediments. Appl Environ Microbiol. 2015;81:8478-88.

16. Xiong J, Li D, Li H, He M, Miller SJ, Yu L, et al. Genome analysis and characterization of zinc efflux systems of a highly zinc-resistant bacterium, Comamonas testosteroni S44. Res Microbiol. 2011;162:671-9.

17. Li J, Yu H, Wu X, Shen L, Liu Y, Qiu G, et al. Novel hyper antimony-oxidizing bacteria isolated from contaminated mine soils in China. Geomicrobiol J. 2018;35:713-20.

18. Zeng W, Li F, Wu C, Yu R, Wu X, Shen L, et al. Role of extracellular polymeric substance (EPS) in toxicity response of soil bacteria Bacillus sp. S3 to multiple heavy metals. Bioprocess Biosyst Eng. 2019:1-15.

19. Yang T, Irene K, Liu H, Liu S, Zhang X, Xu M, et al. Enhanced extracellular gamma glutamyl transpeptidase production by overexpressing of PrsA lipoproteins and improving its mRNA stability in Bacillus subtilis and application in biosynthesis of L-theanine. J Biotechnol, 2019;302:85-91.

20. Moore CM, Helmann JD. Metal ion homeostasis in Bacillus subtilis. Curr Opin Microbiol. 2005;8:188-95.

21. Lehr CR, Kashyap DR, McDermott TR. New insights into microbial oxidation of antimony and arsenic. Appl Environ Microbiol. 2007;73:2386-9.

22. Li J, Wang Q, Li M, Yang B, Shi M, Guo W, et al. Proteomics and genetics for identification of a bacterial antimonite oxidase in Agrobacterium tumefaciens. Environ Sci Technol. 2015;49:5980-9.

23. Wang G, Li J, Zhang Y, Zheng S, Liu F. Anaerobic bacterial immobilization and removal of toxic Sb(III) coupled with $\mathrm{Fe}(\mathrm{II}) / \mathrm{Sb}$ (III) oxidation and denitrification. Front Microbiol. 2019;10:360.

24. Xu L, Zhang H, Xing YT, Li N, Wang S, Sun J. Complete genome sequence of Sphingobacterium psychroaquaticum strain SJ-25, an aerobic bacterium capable of suppressing fungal pathogens. Curr Microbiol. 2020;77:115-22.

25. Hyatt D, Chen GL, LoCascio PF, Land ML, Larimer FW, Hauser LJ, et al. Prodigal: prokaryotic gene recognition and translation initiation site identification. BMC Bioinform. 2010;11:119.

26. Seemann T. Prokka: rapid prokaryotic genome annotation. Bioinformatics. 2014;30:2068-9.

27. Tian X, Zhang Z, Yang T, Chen M, Li J, Chen F, et al. Comparative genomics analysis of Streptomyces species reveals their adaptation to the marine environment and their diversity at the genomic level. Front Microbiol. 2016;7:998.

28. Kumar S, Stecher G, Tamura K. MEGA7: molecular evolutionary genetics analysis version 7.0 for bigger datasets. Mol Biol Evol. 2016;33:1870-4.

29. Chaudhari NM, Gupta VK, Dutta C. BPGA-an ultra-fast pan-genome analysis pipeline. Sci Rep. 2016;6:24373.

Page $13 / 26$ 
30. Edgar RC. MUSCLE: multiple sequence alignment with high accuracy and high throughput. Nucleic Acids Res. 2004;32:1792-7.

31. Qi J, Luo H, Hao B. CVTree: a phylogenetic tree reconstruction tool based on whole genomes. Nucleic Acids Res. 2004;32:W45-47.

32. Richter M, Rosselló-Móra R, Oliver Glöckner F, Peplies J. JSpeciesWS: a web server for prokaryotic species circumscription based on pairwise genome comparison. Bioinformatics. 2015;32:929-31.

33. Richter M, Rosselló-Móra R. Shifting the genomic gold standard for the prokaryotic species definition. Proc Natl Acad Sci USA. 2009;106:19126-31.

34. Meier-Kolthoff JP, Auch AF, Klenk HP, Göker M. Genome sequence-based species delimitation with confidence intervals and improved distance functions. BMC bioinformatics, 2013;14:60.

35. Darling AE, Mau B, Perna NT. progressiveMauve: multiple genome alignment with gene gain, loss and rearrangement. PLoS One. 2010;5:e11147.

36. Pal C, Bengtsson-Palme J, Rensing C, Kristiansson E, Larsson DJ. BacMet: antibacterial biocide and metal resistance genes database. Nucleic Acids Res. 2013;42:D737-43.

37. Soares SC, Oliveira LC, Jaiswal AK, Azevedo V. Genomic Islands: an overview of current software and future improvements. J Integr Bioinform. 2016;13:82-9.

38. Siguier P, Pérochon J, Lestrade L, Mahillon J, Chandler M. ISfinder: the reference centre for bacterial insertion sequences. Nucleic Acids Res. 2006;34:D32-6.

39. Grissa I, Vergnaud G, Pourcel C. CRISPRFinder: a web tool to identify clustered regularly interspaced short palindromic repeats. Nucleic Acids Res. 2007;35:W52-7.

40. Zhou Y, Liang Y, Lynch KH, Dennis JJ, Wishart DS. PHAST: a fast phage search tool. Nucleic Acids Res. 2011;39:W34752.

41. Weaver S, Shank SD, Spielman SJ, Li M, Muse SV, Pond SLK. Datamonkey 2.0: a modern web application for characterizing selective and other evolutionary processes. Mol Biol Evol. 2018;35:773-7.

42. Li M, Zhang X, Yang H, Li X, Cui Z. Soil sustainable utilization technology: mechanism of flavonols in resistance process of heavy meta. Environ Sci Pollut R. 2018;25:26669-81.

43. Zhong C, Han M, Yu S, Yang P, Li H, Ning K. Pan-genome analyses of 24 Shewanella strains re-emphasize the diversification of their functions yet evolutionary dynamics of metal-reducing pathway. Biotechnol Biofuels. 2018;11:193.

44. Chen F, Cao Y, Wei S, Li Y, Li X, Wang Q, et al. Regulation of arsenite oxidation by the phosphate two-component system PhoBR in Halomonas sp. HAL1. Front Microbiol. 2015;6:923.

45. Hahnke RL, Meier-Kolthoff JP, García-López M, Mukherjee S, Huntemann M, Ivanova NN, et al. Genome-based taxonomic classification of bacteroidetes. Front Microbiol. 2016;7:2003.

46. Xie JB, Du Z, Bai L, Tian C, Zhang Y, Xie JY, et al. Comparative genomic analysis of $\mathrm{N}_{2}$-fixing and non- $\mathrm{N}_{2}-$ fixing Paenibacillus spp.: organization, evolution and expression of the nitrogen fixation genes. PLoS Genet. 2014;10:e1004231.

47. Konstantinidis KT, Tiedje JM. Prokaryotic taxonomy and phylogeny in the genomic era: advancements and challenges ahead. Curr Opin Microbiol. 2007;10:504-9.

48. Sugawara M, Epstein B, Badgley BD, Unno T, Xu L, Reese J. Comparative genomics of the core and accessory genomes of 48 Sinorhizobium strains comprising five genospecies. Genome Biol. 2013;14:R17.

49. Vernikos G, Medini D, Riley DR, Tettelin H. Ten years of pan-genome analyses. Curr Opin Microbiol. 2015;23:148-54.

50. Šmarda P, Bureš P, Horová L, Leitch IJ, Mucina L, Pacini E, et al. Ecological and evolutionary significance of genomic GC content diversity in monocots. Proc Natl Acad Sci USA. 2014;111:E4096-102. 
51. Zhang X, Liu X, Li L, Wei G, Zhang D, Liang Y, et al. Phylogeny, divergent evolution, and speciation of sulfur-oxidizing Acidithiobacillus populations. BMC Genomics. 2019;20:438.

52. Juhas M, Van Der Meer J R, Gaillard M, Harding RM, Hood DW, Crook DW. Genomic islands: tools of bacterial horizontal gene transfer and evolution. FEMS Microbiol Rev. 2009;33:376-93.

53. Tumapa S, Holden MTG, Vesaratchavest M, Wuthiekanun V, Limmathurotsakul D, Chierakul W, et al. Burkholderia pseudomallei genome plasticity associated with genomic island variation. BMC Genomics. 2008;9:190.

54. Zhang Q, Rho M, Tang H, Doak TG, Ye Y. CRISPR-Cas systems target a diverse collection of invasive mobile genetic elements in human microbiomes. Genome Biol. 2013;14:R40.

55. Tripathi C, Mishra H, Khurana H, Dwivedi V, Kamra K, Negi RK. Complete genome analysis of Thermus parvatiensis and comparative genomics of Thermus spp. provide insights into genetic variability and evolution of natural competence as strategic survival attributes. Front Microbiol. 2017;8:1410.

56. Pathak A, Chauhan A, Blom J, Indest KJ, Jung CM, Stothard P. Comparative genomics and metabolic analysis reveals peculiar characteristics of Rhodococcus opacus strain M213 particularly for naphthalene degradation. PLoS One. 2016;11:e0161032.

57. Ochman H, Lawrence JG, Groisman EA. Lateral gene transfer and the nature of bacterial innovation. Nature. 2000;405:299.

58. Wang L, Wang J, Jing C. Comparative genomic analysis reveals organization, function and evolution of ars genes in Pantoea spp. Front Microbiol. 2017;8:471.

59. Moury B, Simon V. dN/dS-based methods detect positive selection linked to trade-offs between different fitness traits in the coat protein of potato virus Y. Mol Biol Evol. 2011;28:2707-17.

60. Wu G, Culley DE, Zhang W. Predicted highly expressed genes in the genomes of Streptomyces coelicolor and Streptomyces avermitilis and the implications for their metabolism. Microbiology. 2005;151:2175-87.

\section{Tables}

Table 1 Genomic features of the chromosome and plasmid of Bacillus sp. S3

\begin{tabular}{lll}
\hline Features & Chromosome & Plasmid \\
\hline Genome size (bp) & $5,579,638$ & 241,339 \\
Protein-coding genes & 5,131 & 234 \\
Gene Length (bp): & $4,638,424$ & 203,412 \\
Gene Average Length (bp): & 904 & 869 \\
Gene Length /Genome (\%): & $85.35 \%$ & $84.28 \%$ \\
GC Content in gene region (\%): & $41.17 \%$ & $37.63 \%$ \\
G+C\% numbers & $40.30 \%$ & $36.74 \%$ \\
tRNAs & 104 & 0 \\
rRNAs & 36 & 0 \\
Gls & 12 & 3 \\
CRISPRs & 4 & 0 \\
Prophages & 5 & 0 \\
Transposase genes of IS elements & 115 & 48 \\
\hline
\end{tabular}


Table 2 Genomes statistical information of the $\mathbf{4 5}$ strains used in this study.

\begin{tabular}{|c|c|c|c|c|c|c|c|c|c|}
\hline No. & Organism & $\mathrm{NCBI}$ accession NO. & Level & $\begin{array}{l}\text { Size } \\
(\mathrm{Mb})\end{array}$ & GC\% & $\begin{array}{l}\text { No. of } \\
\text { Genes }\end{array}$ & $\begin{array}{c}\text { No. of } \\
\text { Proteins }\end{array}$ & rRNA & tRNA \\
\hline 1 & Bacillus asahii OM18 & NZ_CP026095 & Complete & 4.89 & 37.45 & 4,824 & 4,419 & 54 & 150 \\
\hline 2 & B. bataviensis LMG 21833 & AJLS00000000.1 & Contig & 5.37 & 39.6 & 5,238 & 5,207 & - & 23 \\
\hline 3 & B. cereus SJ1 & ADFM00000000.1 & Contig & 5.16 & 35.4 & 2,192 & 2,184 & - & 8 \\
\hline 4 & B. cucumis Strain V32-6 & PGVE00000000.1 & Contig & 5.71 & 38.6 & 5,552 & 5,309 & 10 & 129 \\
\hline 5 & B. dielmoensis $\mathrm{FF} 4(\mathrm{~T})$ & NZ_CCAD000000000 & Complete & 4.57 & 40.9 & 4,433 & 4,184 & 20 & 136 \\
\hline 6 & B. drentensis NBRC 102427 & BCUX00000000.1 & Contig & 5.16 & 38.7 & 4,998 & 4,851 & - & 28 \\
\hline 7 & B. drentensis strain FJAT-10044 & LUUU00000000.1 & Scaffold & 5.3 & 38.9 & 5,163 & 4,890 & 51 & 125 \\
\hline 8 & B. firmus NBRC 15306 & BCUY00000000.1 & Contig & 4.42 & 41.7 & 4,515 & 4,170 & - & 26 \\
\hline 9 & B. firmus NCTC10335 & UFTC00000000.1 & Contig & 4.8 & 41.7 & 4,948 & 4,436 & 36 & 108 \\
\hline 10 & B. firmus strain 14_TX & QNSF00000000.1 & Scaffold & 5.84 & 40.8 & 6,009 & 5,834 & 23 & 102 \\
\hline 11 & B. glycinifermentans BGLY & LT603683.1 & Complete & 4.61 & 46.1 & 4,735 & 4,381 & 24 & 82 \\
\hline 12 & $\begin{array}{l}\text { B. glycinifermentans } \\
\text { SRCM103574 }\end{array}$ & СР035232.1 & Complete & 4.81 & 46.01 & 4,948 & 4,572 & 25 & 82 \\
\hline 13 & B. licheniformis ATCC 14580 & СР000002.3 & Complete & 4.22 & 46.20 & 4,382 & 4,219 & 21 & 72 \\
\hline 14 & B. licheniformis strain YNP1-TSU & NZ_CM007615.1 & Chromosome & 4.25 & 45.9 & 4,388 & 4,227 & 4 & 66 \\
\hline 15 & B. mesonae strain FJAT-13985 & LUUQ00000000.1 & Scaffold & 5.81 & 40.3 & 5,553 & 5,309 & 40 & 104 \\
\hline 16 & B. mesonae strain $\mathrm{H} 20-5$ & СР022572.1 & Complete & 5.84 & 40.4 & 5,600 & 5,330 & 41 & 109 \\
\hline 17 & B. methanolicus MGA3 & СР007739.1 & Complete & 3.34 & 38.7 & 3,355 & 3,092 & 27 & 91 \\
\hline 18 & B. niacini strain DSM 2923 & JRYQ00000000.1 & Scaffold & 2.2 & 38.3 & 2,167 & 1,922 & 3 & 35 \\
\hline 19 & B. novalis NBRC 102450 & NZ_BCVP00000000.1 & Contig & 5.57 & 39.9 & 5,387 & 5,212 & - & 31 \\
\hline 20 & B. novalis strain FJAT-14227 & LUUR00000000.1 & Scaffold & 5.67 & 40 & 5,517 & 5,247 & 37 & 118 \\
\hline 21 & $\begin{array}{l}\text { B. oceanisediminis strain } \\
\text { Bhandara28 }\end{array}$ & MBRJ00000000.1 & Contig & 5.88 & 40.8 & 5,925 & 5,705 & 33 & 106 \\
\hline 22 & B. soliNBRC 102451 & BCVI00000000.1 & Contig & 5.46 & 39.5 & 5,289 & 5,109 & 3 & 18 \\
\hline 23 & B. soli strain DSM 15604 & NISV00000000.1 & Scaffold & 5.58 & 39.7 & 5,451 & 5,148 & 43 & 92 \\
\hline 24 & $\begin{array}{l}\text { B. subtilis subsp. spizizenii str. } \\
\text { W23 }\end{array}$ & СР002183.1 & Complete & 4.03 & 43.9 & 4,116 & 3,912 & 24 & 77 \\
\hline 25 & B. subtilis subsp. subtilis str. 168 & AL009126.3 & Complete & 4.22 & 43.5 & 4,536 & 4,237 & 30 & 86 \\
\hline 26 & $\begin{array}{l}\text { B. thuringiensis serovar konkukian } \\
\text { str. } 97-27\end{array}$ & AE017355.1 & Complete & 5.24 & 35.4 & 5,263 & 5,117 & 41 & 105 \\
\hline 27 & B. thuringiensis YBT-1518 & СР005935.1 & Complete & 6 & 35.4 & 6,371 & 5,837 & 45 & 90 \\
\hline 28 & B. viretiLMG 21834 & ALAN00000000.1 & Contig & 5.28 & 39.7 & 5,106 & 5,084 & - & 21 \\
\hline 29 & B. viretiStrain DSM 15602 & LDNB00000000.1 & Scaffold & 5.31 & 39.8 & 5,118 & 4,794 & 13 & 89 \\
\hline 30 & B. velezensis FZB42 & СР000560.1 & Complete & 3.91 & 46.5 & 3,892 & 3,687 & 29 & 88 \\
\hline 31 & Bacillus sp. AFS006103 & NTXX00000000. & Scaffold & 5.18 & 38.6 & 5,018 & 4,840 & 5 & 92 \\
\hline 32 & Bacillus sp. OK048 & FNHN00000000.1 & Scaffold & 5.17 & 38 & 5,225 & 5,058 & 25 & 115 \\
\hline 33 & Bacillus sp. OV166 & FXWM00000000.1 & Contig & 7.08 & 38.3 & 7,182 & 6,561 & 60 & 152 \\
\hline 34 & Bacillus sp. UNC41MFS5 & JMLP00000000.1 & Scaffold & 3.27 & 38.6 & 3,107 & 3,014 & 6 & 25 \\
\hline 35 & Bacillus sp. UNC438CL73TsuS30 & AXVA00000000.1 & Scaffold & 3.06 & 39 & 2,983 & 2,867 & 6 & 41 \\
\hline 36 & Bacillus sp. LF1 & CVRB00000000.1 & Contig & 5.6 & 38.1 & 5,524 & 5,277 & 17 & 102 \\
\hline 37 & Bacillus sp. FJAT-18017 & СР012602.1 & Complete & 5.27 & 42.4 & 5,018 & 4,825 & 30 & 85 \\
\hline 38 & Bacillus sp. FJAT-29814 & LMTJ00000000.1 & Scaffold & 5.89 & 41.9 & 5,791 & 5,596 & 11 & 85 \\
\hline 39 & Bacillus sp. X1 & СР008855.1 & Complete & 3.42 & 38.1 & 3,433 & 3,103 & 36 & 122 \\
\hline 40 & Bacillus sp. MUM 116 & MLYR00000000.1 & Contig & 5.72 & 38.4 & 5,600 & 5,273 & 25 & 165 \\
\hline 41 & Bacillus sp. 0xB-1 & AP013294.1 & Complete & 3.59 & 47.8 & 3,604 & 3,438 & 22 & 83 \\
\hline 42 & Bacillus sp. WN066 & SMYO00000000.1 & Contig & 6.21 & 38.6 & 6,131 & 5,757 & 36 & 151 \\
\hline 43 & Bacillus sp. 7884-1 & NPDD00000000.1 & Contig & 6 & 38 & 5,848 & 5,597 & - & 46 \\
\hline 44 & Bacillus sp. MRMR6 & MSLS00000000.1 & Contig & 5.44 & 38.8 & 5,276 & 4,978 & 50 & 108 \\
\hline 45 & Bacillus sp. \$3 & СР039727 & Complete & 5.58 & 40.3 & 5,131 & 5,344 & 104 & 36 \\
\hline
\end{tabular}


Table 3 Genes associated with putative heavy metal(loid)s resistance in Bacillus sp. S3 


\begin{tabular}{|c|c|c|c|c|}
\hline Category & Gene_ID & Gene & Protein & Function \\
\hline \multirow[t]{5}{*}{$\begin{array}{l}\text { Arsenate/arsenite } \\
\text { detoxification }\end{array}$} & FAY30_05805 & $a i o B$ & $\begin{array}{l}\text { Small subunit of arsenite } \\
\text { oxidase }\end{array}$ & As(III) oxidation \\
\hline & FAY30_02870 & \multirow[t]{3}{*}{ arsB_123 } & \multirow[t]{3}{*}{$\begin{array}{l}\text { Putative arsenical pump } \\
\text { membrane protein }\end{array}$} & \multirow[t]{3}{*}{ As(III) efflux pump } \\
\hline & FAY30_09810 & & & \\
\hline & FAY30_12790 & & & \\
\hline & FAY30_09815 & ars $C$ & Arsenate reductase & As $(\mathrm{V})$ reduction \\
\hline \multirow[t]{3}{*}{ Copper detoxification } & $\begin{array}{l}\text { FAY30_07975 } \\
\text { FAY30_15235 } \\
\text { FAY30_16820 } \\
\text { FAY30_16835 }\end{array}$ & copA_1234 & $\begin{array}{c}\text { Copper-exporting P-type ATPase; } \\
\text { Lead, cadmium, zinc and } \\
\text { mercury transporting ATPase }\end{array}$ & $\begin{array}{c}\text { Cation translocation } \\
\text { P-type ATPase }\end{array}$ \\
\hline & $\begin{array}{l}\text { FAY30_11165 } \\
\text { FAY30_16840 }\end{array}$ & $\operatorname{cop} Z_{-} 12$ & Copper chaperone & \\
\hline & FAY30_05265 & cutC & Copper homeostasis protein & \\
\hline \multirow[t]{2}{*}{ Chromate detoxification } & FAY30_22440 & chrR & Chromate reductase & \\
\hline & $\begin{array}{l}\text { FAY30_11465 } \\
\text { FAY30_20185 } \\
\text { FAY30_20190 }\end{array}$ & ChrA_123 & Chromate transport protein & \\
\hline \multirow[t]{12}{*}{$\begin{array}{l}\text { Cadmium, zinc, cobalt, } \\
\text { mercury detoxification }\end{array}$} & FAY30_09760 & $\operatorname{cad} C$ & $\begin{array}{c}\text { Cadmium resistance } \\
\text { transcriptional regulatory } \\
\text { protein }\end{array}$ & \\
\hline & FAY30_09765 & $\operatorname{cad} A$ & $\begin{array}{l}\text { putative cadmium-transporting } \\
\text { ATPase }\end{array}$ & \\
\hline & FAY30_21075 & zирT & Zinc transporter & \\
\hline & FAY30_06055 & $z O S A$ & Zinc-transporting ATPase & \\
\hline & FAY30_11960 & yeiR & Zinc-binding GTPase & \\
\hline & FAY30_17115 & zur & Zinc uptake regulation protein & \\
\hline & FAY30_15605 & znuA & $\begin{array}{l}\text { Zinc ABC transporter, substrate- } \\
\text { binding protein }\end{array}$ & \\
\hline & FAY30_20065 & $z \cap u B$ & $\begin{array}{l}\text { Zinc ABC transporter, permease } \\
\text { protein }\end{array}$ & \\
\hline & FAY30_08125 & znuC & $\begin{array}{l}\text { Zinc ABC transporter, ATP- } \\
\text { binding protein }\end{array}$ & \\
\hline & FAY30_20440 & $C Z C D$ & $\begin{array}{l}\text { Cadmium, cobalt and zinc/H(+)- } \\
\mathrm{K}(+) \text { antiporter }\end{array}$ & $\begin{array}{l}\text { Cation efflux system } \\
\text { protein }\end{array}$ \\
\hline & FAY30_10430 & corc & $\begin{array}{l}\text { Magnesium and cobalt efflux } \\
\text { protein }\end{array}$ & \\
\hline & FAY30_24820 & corA & $\begin{array}{l}\text { Cobalt/magnesium transport } \\
\text { protein }\end{array}$ & \\
\hline
\end{tabular}




\begin{tabular}{|c|c|c|c|c|} 
& & merR & $\begin{array}{c}\text { Mercuric resistance operon } \\
\text { regulatory protein }\end{array}$ & \\
\hline $\begin{array}{c}\text { Nickel, molybdenum, } \\
\text { detoxification }\end{array}$ & FAY30_20460 & nikMN & nickel transport protein & \\
\hline & FAY30_20940 & modA & $\begin{array}{c}\text { Molybdate-binding periplasmic } \\
\text { protein }\end{array}$ & \\
\hline & FAY30_18400 & modB & $\begin{array}{c}\text { Molybdenum transport system } \\
\text { permease protein }\end{array}$ & \\
\hline Other detoxification & FAY30_10280 & mntH & $\begin{array}{c}\text { Divalent metal cation } \\
\text { transporter }\end{array}$ & \\
\hline
\end{tabular}

Table 4 Average nucleotide identities (ANI) analysis of Bacillus sp. S3 and other Bacillus species.

\begin{tabular}{|c|c|c|c|c|c|c|c|c|c|c|c|c|c|c|c|}
\hline & s3 & $\begin{array}{l}\text { LMG } \\
21833\end{array}$ & $\begin{array}{l}\text { LMG } \\
21834\end{array}$ & $\begin{array}{l}\text { DSM } \\
15602\end{array}$ & $\begin{array}{l}\text { NBRC } \\
102451\end{array}$ & $\begin{array}{l}\text { DSM } \\
15604\end{array}$ & $\begin{array}{l}\text { NBRC } \\
102450\end{array}$ & $\begin{array}{l}\text { FJAT- } \\
14227\end{array}$ & $\begin{array}{l}\text { ATCC } \\
14580\end{array}$ & $\begin{array}{l}\text { YNP1- } \\
\text { TSU }\end{array}$ & OM18 & LF1 & W23 & 168 & OK048 \\
\hline $\begin{array}{l}\text { Bacillus sp. } \\
\text { s3 }\end{array}$ & 100 & 81.68 & 78.48 & 78.47 & 78.34 & 78.37 & 78.25 & 78.3 & 67.49 & 66.8 & 69.62 & 74.47 & 67.72 & 67.8 & 74.02 \\
\hline $\begin{array}{l}\text { B. } \\
\text { bataviensis } \\
\text { LMG } 21833\end{array}$ & 81.34 & 100 & 78.7 & 78.68 & 78.84 & 78.84 & 78.99 & 78.98 & 66.61 & 66.49 & 69.28 & 74.06 & 66.92 & 66.99 & 73.69 \\
\hline $\begin{array}{l}\text { B. vireti LMG } \\
21834\end{array}$ & 78.25 & 78.78 & 100 & 99.99 & 79.6 & 79.61 & 89.59 & 89.59 & 66.72 & 66.61 & 68.86 & 74.48 & 66.77 & 66.86 & 73.94 \\
\hline $\begin{array}{l}\text { B. vireti } \\
\text { strain DSM } \\
15602\end{array}$ & 78.15 & 78.7 & 99.98 & 100 & 79.7 & 79.7 & 89.6 & 89.61 & 66.75 & 66.65 & 68.79 & 74.42 & 66.85 & 66.91 & 73.99 \\
\hline $\begin{array}{l}\text { B. soli NBRC } \\
102451\end{array}$ & 78.06 & 78.73 & 79.74 & 79.74 & 100 & 99.99 & 80.58 & 80.6 & 66.51 & 66.45 & 69.01 & 74.81 & 66.75 & 66.79 & 74.28 \\
\hline $\begin{array}{l}\text { B. soli strain } \\
\text { DSM } 15604\end{array}$ & 78.39 & 79.05 & 79.94 & 79.92 & 99.99 & 100 & 80.76 & 80.78 & 67.61 & 66.9 & 69.99 & 75.11 & 67.9 & 67.92 & 74.83 \\
\hline $\begin{array}{l}\text { B. novalis } \\
\text { NBRC } \\
102450\end{array}$ & 78 & 78.97 & 89.46 & 89.46 & 80.6 & 80.61 & 100 & 100 & 66.7 & 66.6 & 68.54 & 74.53 & 66.69 & 66.71 & 74.08 \\
\hline $\begin{array}{l}\text { B. novalis } \\
\text { FJAT-14227 }\end{array}$ & 78.42 & 79.31 & 89.58 & 89.56 & 80.66 & 80.7 & 99.99 & 100 & 67.63 & 67.04 & 69.49 & 74.92 & 67.55 & 67.76 & 74.43 \\
\hline $\begin{array}{l}\text { B. } \\
\text { licheniformis } \\
\text { ATCC } 14580\end{array}$ & 67.35 & 67.09 & 67.24 & 67.29 & 67.08 & 67.16 & 67.32 & 67.33 & 100 & 99.57 & 66.99 & 67.12 & 72.15 & 72.16 & 67.13 \\
\hline $\begin{array}{l}\text { B. } \\
\text { licheniformis } \\
\text { YNP1-TSU }\end{array}$ & 66.76 & 66.55 & 66.71 & 66.73 & 66.54 & 66.58 & 66.86 & 66.88 & 99.41 & 100 & 66.6 & 66.58 & 71.83 & 71.75 & 66.74 \\
\hline $\begin{array}{l}\text { B. asahii } \\
\text { strain OM18 }\end{array}$ & 70.12 & 70.21 & 69.86 & 69.8 & 70 & 70.05 & 69.79 & 69.85 & 67.96 & 67.09 & 100 & 70.07 & 68.52 & 68.46 & 69.93 \\
\hline $\begin{array}{l}\text { Bacillus sp. } \\
\text { LF1 }\end{array}$ & 74.3 & 74.32 & 74.64 & 74.66 & 75.01 & 75.04 & 74.75 & 74.8 & 66.83 & 66.64 & 69.47 & 100 & 67.14 & 67.19 & 73.34 \\
\hline $\begin{array}{l}\text { B. subtilis } \\
\text { subsp. str. } \\
\text { W23 }\end{array}$ & 67.61 & 67.52 & 67.49 & 67.44 & 67.38 & 67.43 & 67.48 & 67.54 & 72.12 & 71.88 & 67.83 & 67.47 & 100 & 92.5 & 67.29 \\
\hline $\begin{array}{l}\text { B. subtilis } \\
\text { subsp. str. } \\
168\end{array}$ & 67.67 & 67.62 & 67.53 & 67.47 & 67.46 & 67.45 & 67.52 & 67.53 & 72.14 & 71.82 & 67.87 & 67.53 & 92.23 & 100 & 67.57 \\
\hline $\begin{array}{l}\text { Bacillus sp. } \\
\text { OK048 }\end{array}$ & 74.04 & 73.97 & 74.26 & 74.3 & 74.56 & 74.59 & 74.21 & 74.26 & 66.58 & 66.53 & 69.16 & 73.35 & 66.86 & 66.85 & 100 \\
\hline
\end{tabular}


Figures in green denote strains belonging to the same species. The asterisk indicates that the strain is compared to itself, which does not provide valuable information.

\section{Figures}
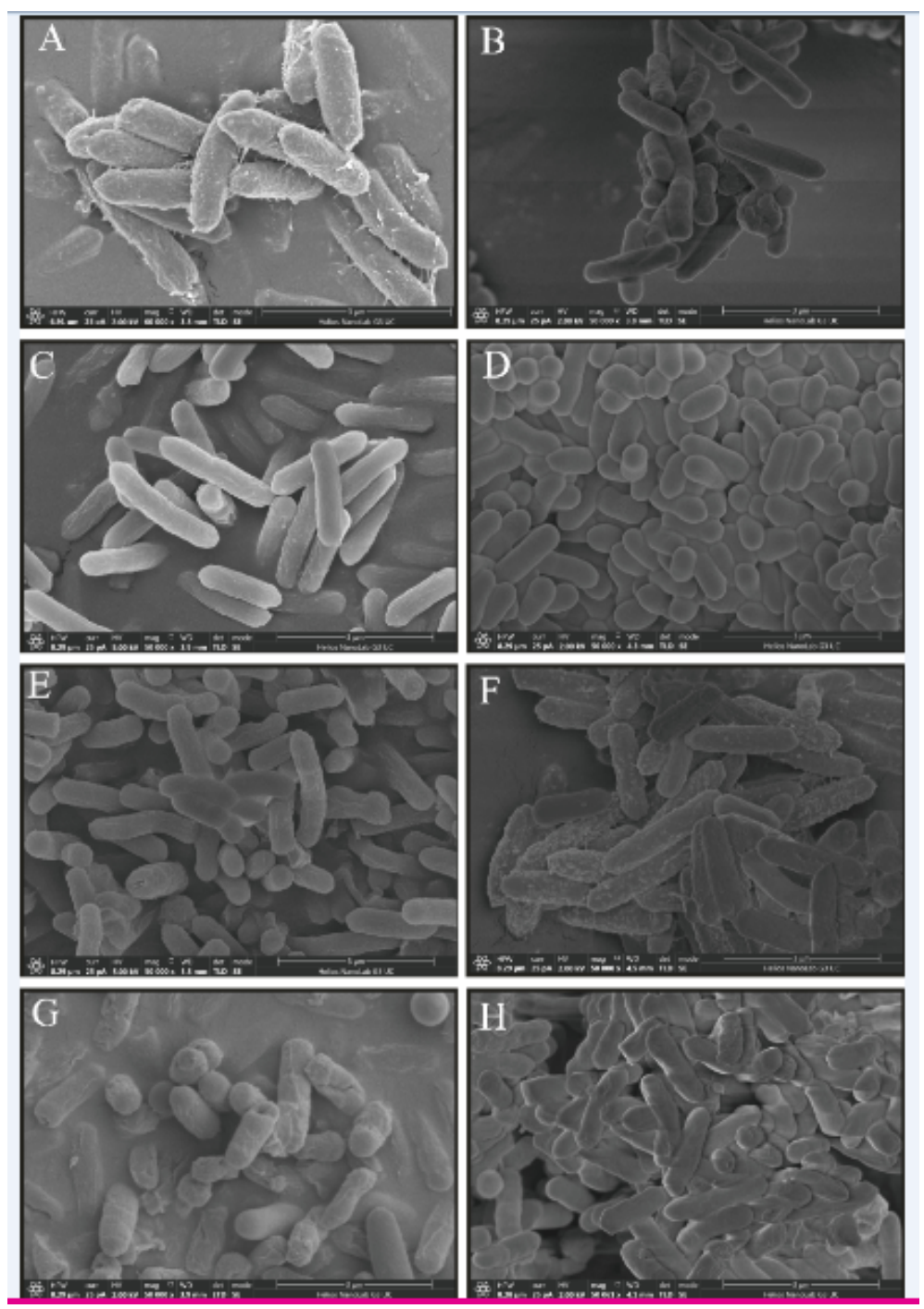

\section{Figure 1}

Scanning electron microscope (SEM) micrograph of Bacillus sp. S3 before and after the various heavy metal ions exposure: CK (A); Sb(III) (B); $\mathrm{As}(\mathrm{III})(\mathrm{C})$; $\mathrm{Cd}(\mathrm{II})(\mathrm{D})$; $\mathrm{Cr}(\mathrm{VI})$ (E); $\mathrm{Pb}(\mathrm{II})(\mathrm{F})$; $\mathrm{Cu}(\mathrm{II})(\mathrm{G}) ; \mathrm{Zn}(\mathrm{II})(\mathrm{H})$. 

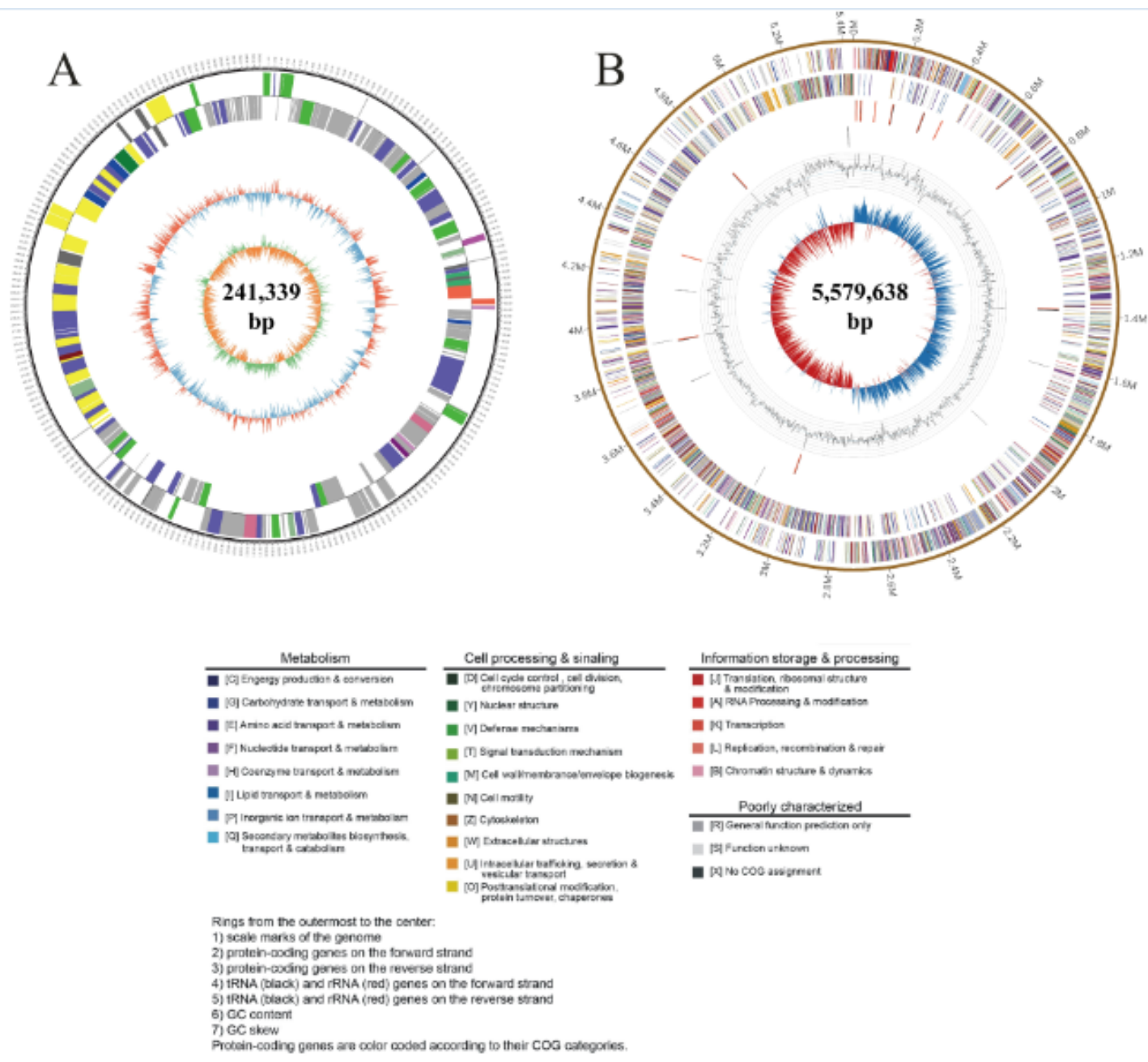

Figure 2

Circular genome maps of Bacillus sp. S3 chromosome (A) and plasmid (B). From the outer to the inner circle: (1) scale marks of genomes; (2) assigned COG classes of protein-coding genes (CDSs) on the forward strand as indicated by relevant colors; (3) forward strand CDSs; (4) tRNA(black) and rRNA(red) genes on the forward strand; (5) tRNA(black) and rRNA(red) genes on the reversed strand; (6) GC content (swell outward/inward indicates higher/lower G+C compared with the average $\mathrm{G}+\mathrm{C}$ content); (7) GC skew (cyan/red indicate positive/negative values). 


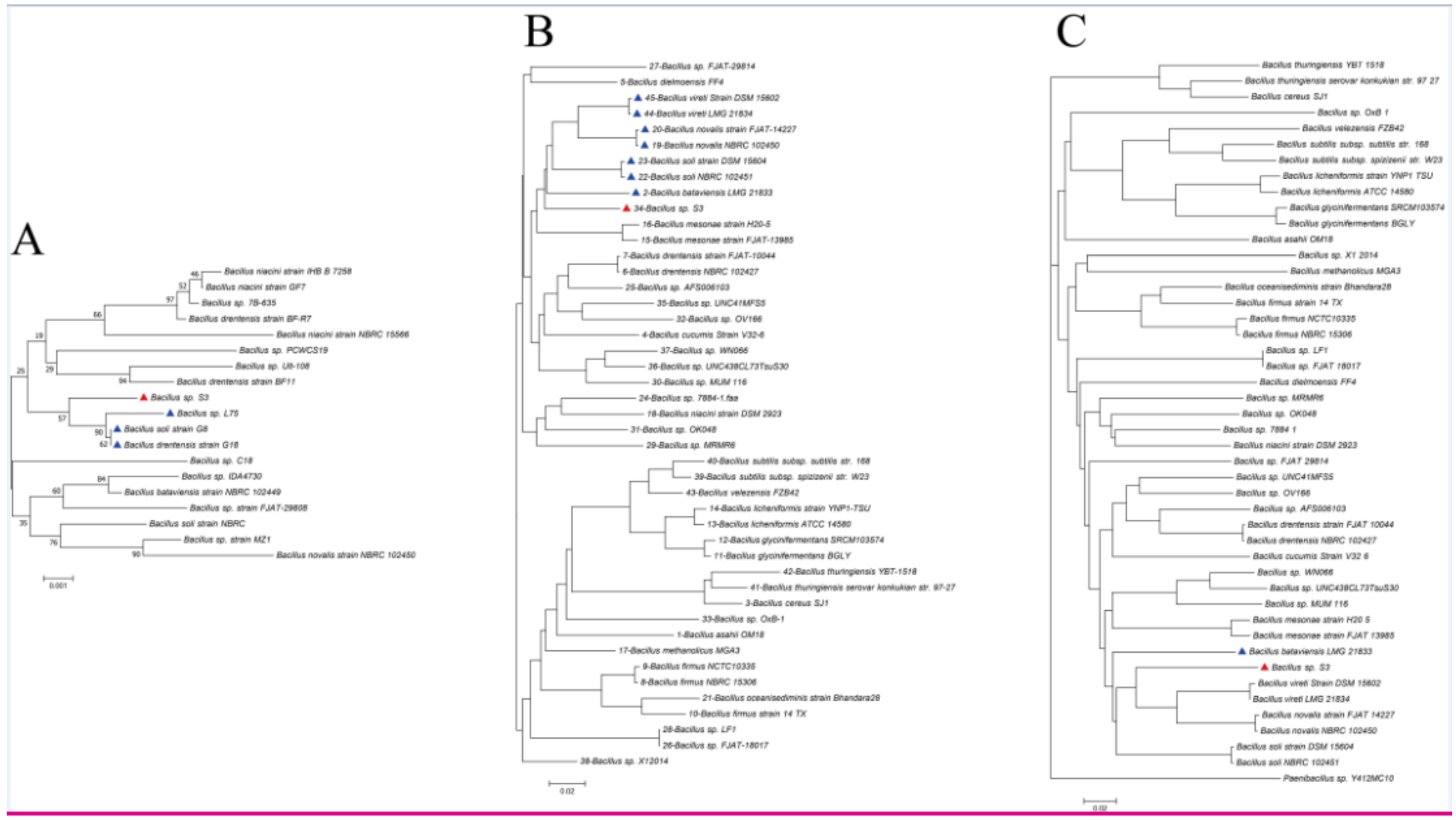

\section{Figure 3}

Phylogenetic relationships of 45 Bacillus strains. Phylogenetic trees based on (A)16S rRNA genes derived from Bacillus sp. S3 and other close-related strains. (B) 554 core genes. Bootstrap values are indicated at each node based on a total of 1,000 bootstrap replicates. (C) Whole-genome-based phylogeny trees using a composition vector (CV) approach. Bacillus sp. S3 with other closely related strains formed a group were marked in blue and S3 was marked in red blot. Encephalitozoon cuniculi GB M1 is regarded as an out group. 

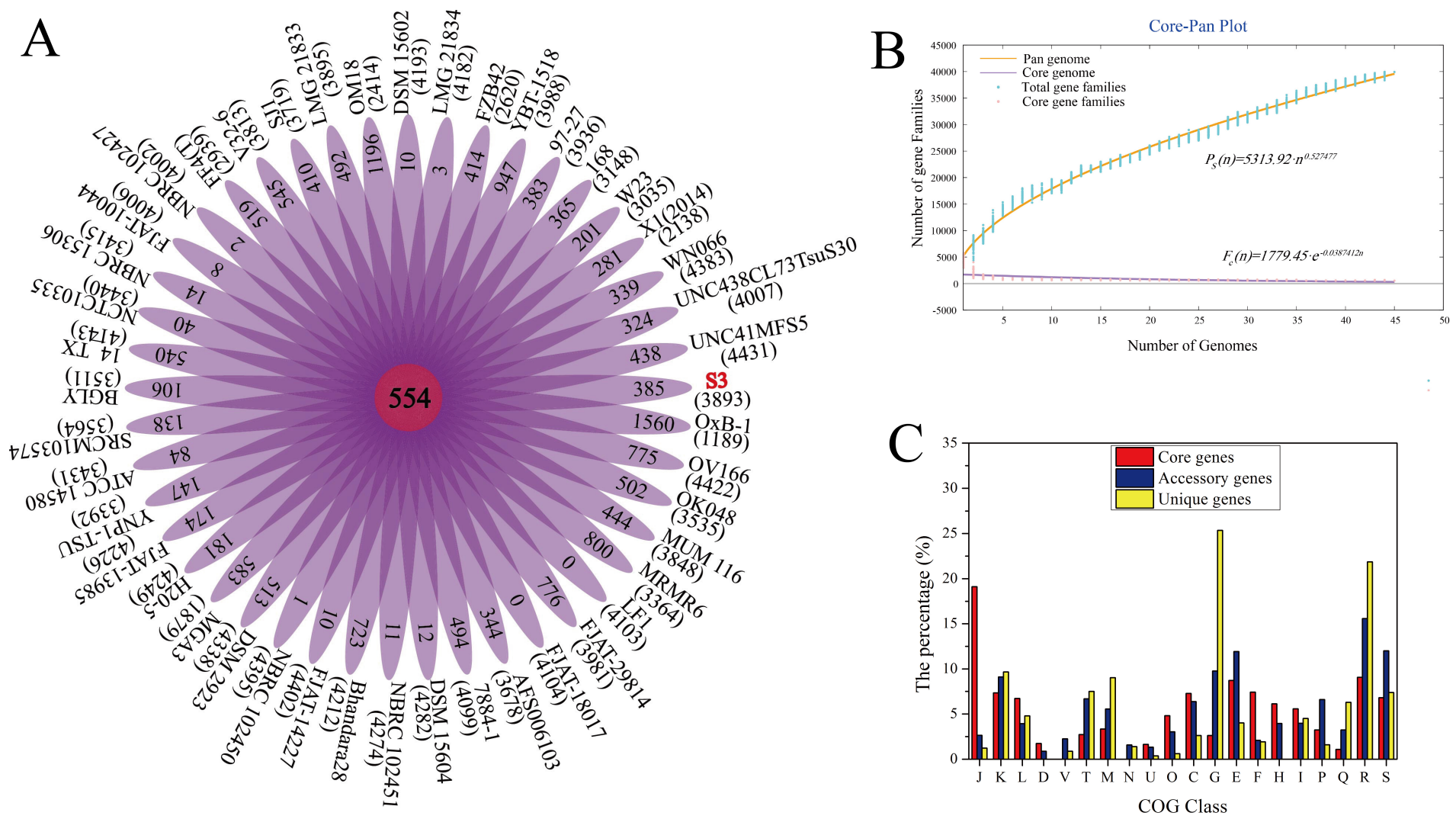

Figure 4

Pan genome analysis of strains within the Bacillus genus. (A) Venn diagram displaying the numbers of core gene and flexible genes for each of the 45 Bacillus strains. (B) Mathematical modeling of the pan-genome and core genome of Bacillus. (C) Proportion of genes enriched in the clusters of orthologous groups (COG) categories in unique genes, accessory genome, and pan-genome according to COG database. 


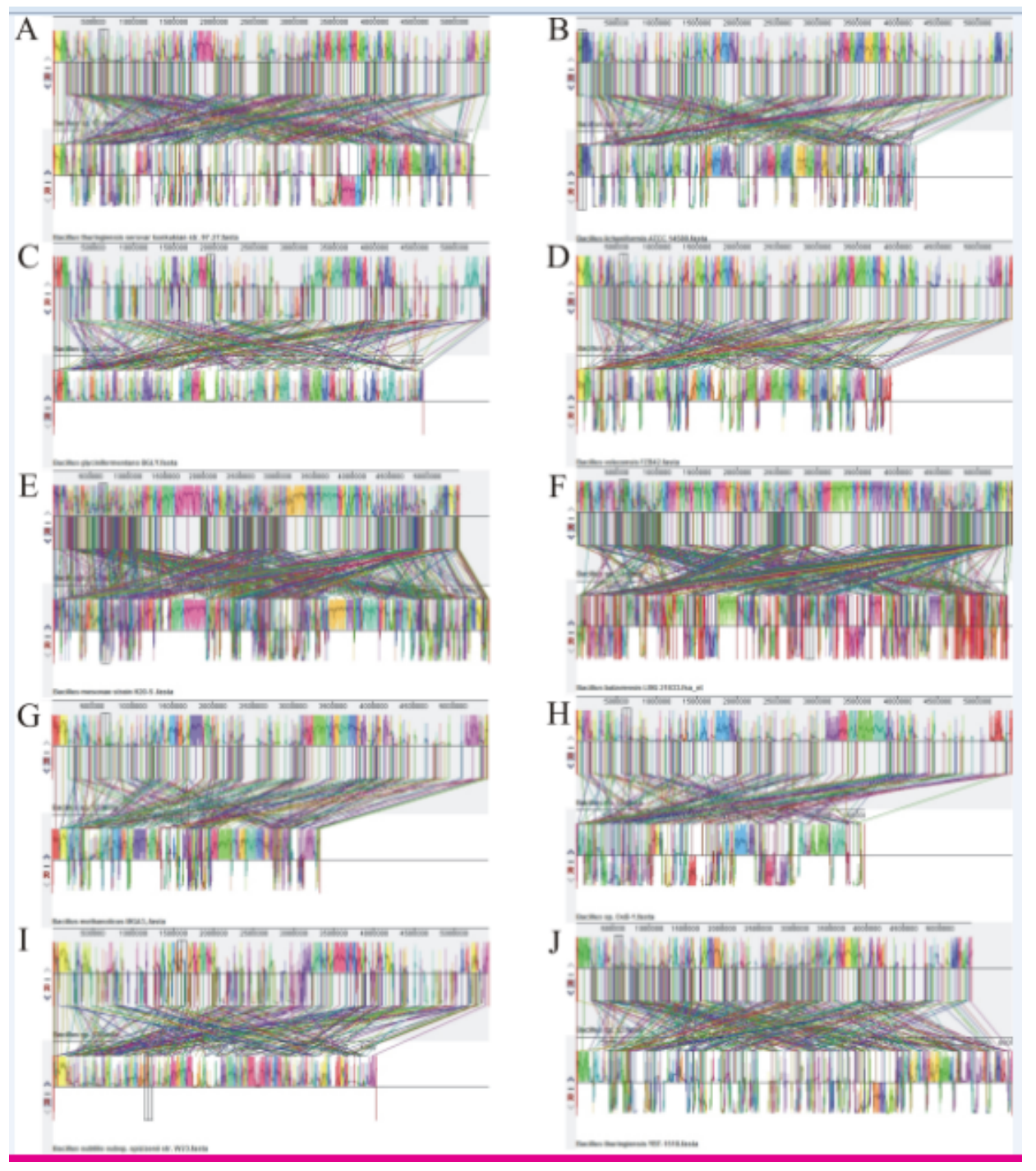

Figure 5

Whole genomes comparative alignment of Bacillus sp. S3 with 10 selected Bacillus strain. Bacillus thuringiensis serovar konkukian str. 97-27 (A); Bacillus licheniformis ATCC 14580 (B); Bacillus glycinifermentans BGLY (C); Bacillus velezensis FZB42 (D); Bacillus mesonae strain H20-5 (E); Bacillus bataviensis LMG 21833 (F); Bacillus methanolicus MGA3 (G); Bacillus sp. OxB-1 (H); Bacillus subtilis subsp. spizizenii str. W23 (I); Bacillus thuringiensis YBT-1518 (J). Boxes of different colors demonstrate the sequence coordinates and the conserved segments represented locally collinear blocks (LCBs) (or locally conserved regions). The LCBs above and below the reference line of the consistent color represent the orientation of the LCBs relative to the reference sequence for each genome. White areas represent possibly contain genome-specific sequence elements and those genomic positions that did not adequately align between the selected genomes. 

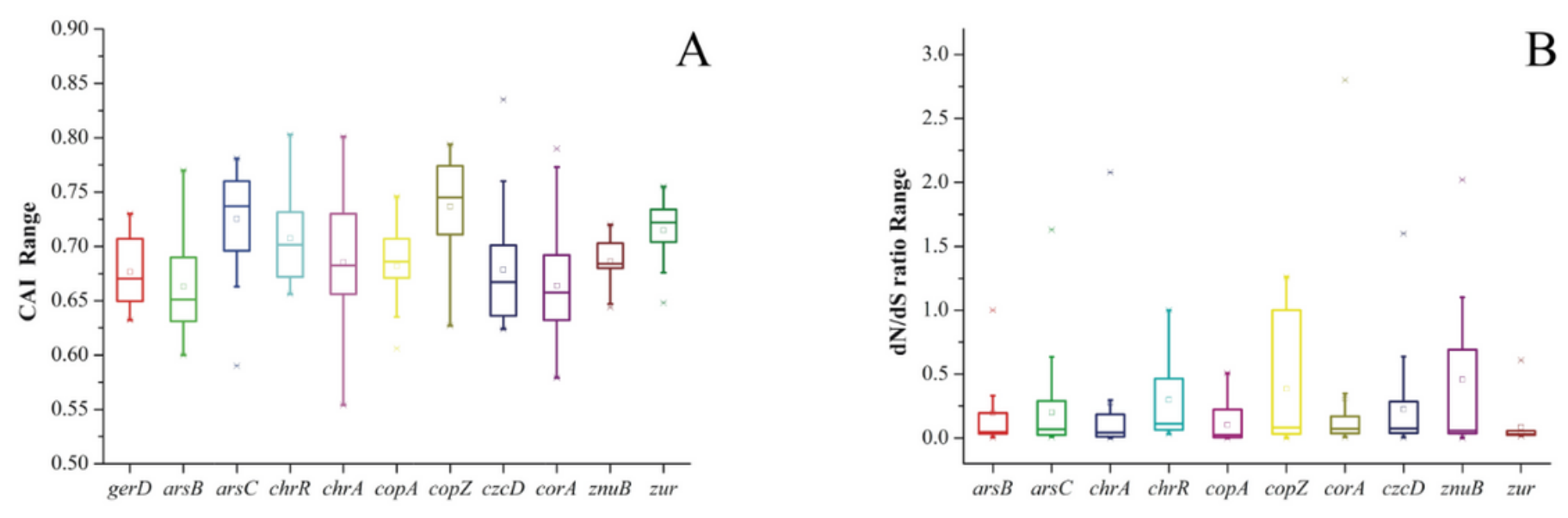

Figure 6

Distributions and range of selection pressure on various metal resistance genes within the genus Bacillus (A). Range of CAl values of different metal resistance genes of Bacillus species with gerD gene as a reference(B).

A

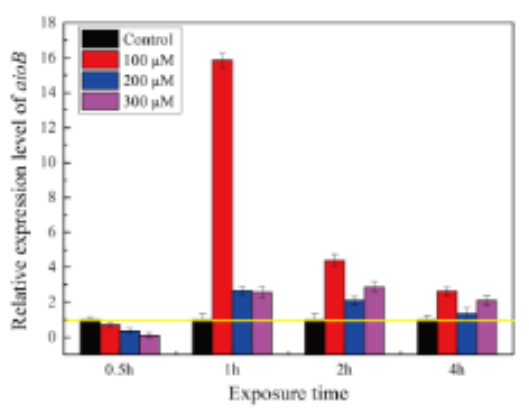

$\mathrm{C}$

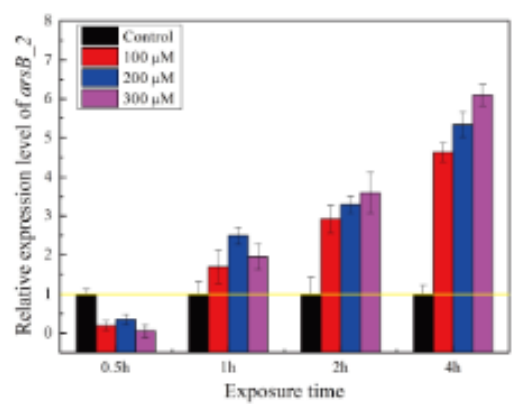

$\mathrm{E}$

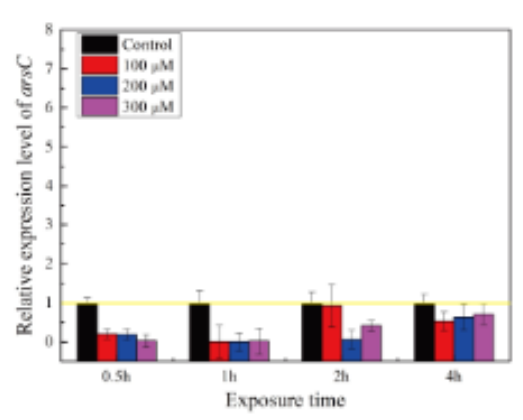

$\mathrm{B}$

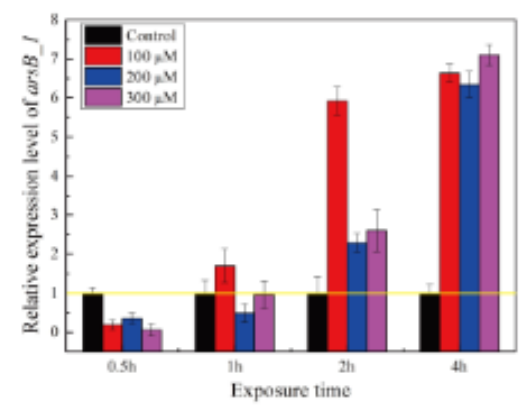

$\mathrm{D}$

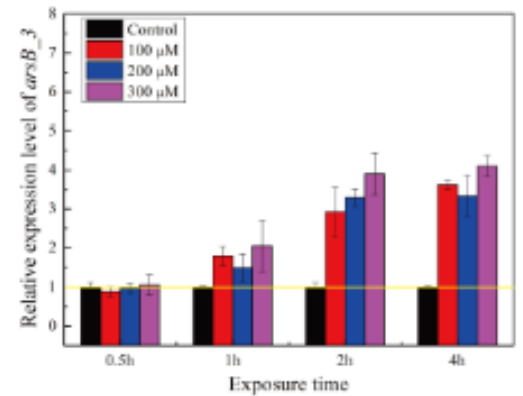

$\mathrm{F}$

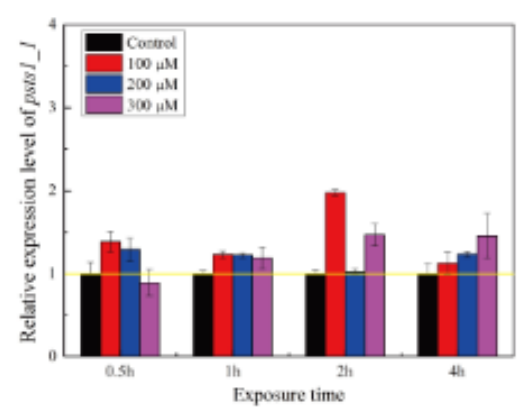

Figure 7 
Quantitative reverse transcriptase-PCR analysis of the genes encoding proteins involved in antimonite/arsenate oxidation $(A)$, antimonite/arsenite resistance $(B, C, D)$, antimonate/arsenate reductase $(E)$ and phosphate metabolism (F). Date shown as the mean of three replicates, with the error bars representing \pm SD.

\section{Supplementary Files}

This is a list of supplementary files associated with this preprint. Click to download.

- TBCP5282p.fasta

- TBCP5282g.gbk

- TableS7dDDH.xlsx

- TableS5GO.xlsx

- TableS6KEGG.xlsx

- Tables9.xlsx

- Tables8Mobilegeneticelements.xlsx

- Supplementarymaterial.docx

- TBCP5282g.fasta

- TBCP5282p.gbk

- Tables2.xIsx

- Tables1.xIsx

- Tables3.xlsx

- Tables4COG.xIsx 